University of New Hampshire

University of New Hampshire Scholars' Repository

Jackson Estuarine Laboratory

Institute for the Study of Earth, Oceans, and

Space (EOS)

1970

\title{
Atlantic deep-sea calanoid Copepoda
}

Ellsworth $\mathrm{H}$. Wheeler

Follow this and additional works at: https://scholars.unh.edu/jel

\section{Comments}

This is an article published by The Smithsonian Institution in Smithsonian Contributions to the Marine Sciences, in

1970, available online: https://doi.org/10.5479/si.00810282.55

\section{Recommended Citation}

Wheeler, E.H., Jr. 1970. Atlantic Deep-Sea Calanoid Copepoda. Smithsonian Contributions to Zoology 55:1-30. US Government Printing Office, Washington, DC.

This Article is brought to you for free and open access by the Institute for the Study of Earth, Oceans, and Space (EOS) at University of New Hampshire Scholars' Repository. It has been accepted for inclusion in Jackson Estuarine Laboratory by an authorized administrator of University of New Hampshire Scholars' Repository. For more information, please contact Scholarly.Communication@unh.edu. 
ELLSWORTH H. WHEELER, 3R. Atlantic
Deep-Sea Calanoid Copepoda 


\section{SERIAL PUBLICATIONS OF THE SMITHSONIAN INSTITUTION}

The emphasis upon publications as a means of diffusing knowledge was expressed by the first Secretary of the Smithsonian Institution. In his formal plan for the Institution, Joseph Henry articulated a program that included the following statement: "It is proposed to publish a series of reports, giving an account of the new discoveries in science, and of the changes made from year to year in all branches of knowledge not strictly professional." This keynote of basic research has been adhered to over the years in the issuance of thousands of titles in serial publications under the Smithsonian imprint, commencing with Smithsonian Contributions to Knowledge in 1848 and continuing with the following active series:

$$
\begin{aligned}
& \text { Smithsonian Annals of Flight } \\
& \text { Smithsonian Contributions to Anthropology } \\
& \text { Smithsonian Contributions to Astrophysics } \\
& \text { Smithsonian Contributions to Botany } \\
& \text { Smithsonian Contributions to the Earth Sciences } \\
& \text { Smithsonian Contributions to Paleobiology } \\
& \text { Smithsonian Contributions to Zoology } \\
& \text { Smithsonian Studies in History and Technology }
\end{aligned}
$$

In these series, the Institution publishes original articles and monographs dealing with the research and collections of its several museums and offices and of professional colleagues at other institutions of learning. These papers report newly acquired facts, synoptic interpretations of data, or original theory in specialized fields. Each publication is distributed by mailing lists to libraries, laboratories, institutes, and interested specialists throughout the world. Individual copies may be obtained from the Smithsonian Institution Press as long as stocks are available.

S. Dillon RIPLey

Secretary

Smithsonian Institution 
SMITHSONIAN CONTRIBUTIONS TO ZOOLOGY

NUMBER 55

\section{Ellsworth H. Wheeler, Jr. Atlantic Deep-Sea Calanoid Copepoda}




\begin{abstract}
A BST RACT
Wheeler, Ellsworth H. Jr. Atlantic Deep-Sea Calanoid Copepoda. Smithsonian Contributions to Zoology, 55: 1-31, 1970.-Calanoid Copepoda from 2,000 m to 4,000 m were collected with closing nets on R.V. Trident cruises 023 and 036 in the North and South Atlantic. Both the Nansen vertical net and the large ClarkeBumpus net are liable to contamination from surface-living species. Of 1,556 calanoid copepods examined, 310 were considered contaminants, 243 were adults, and 1,003 were juveniles.

Abundance of calanoid adults (excluding contaminants) was varied but always less than 29 adults $/ 100 \mathrm{~m}^{3}$. These results are consistent with other investigations. The ratio of numbers of species to numbers of individuals increases with decreasing latitude when data from other Atlantic collections are included. Existing hypotheses explaining latitudinal gradients in diversity do not apparently apply to the 2,000$4,000 \mathrm{~m}$ interval. Diversity in the deep sea is probably echoing that of upper levels. The species assemblage is cosmopolitan, with many species occurring in all oceans.

The total length of adult calanoid copepods averaged $2.14 \mathrm{~mm}$, a value consistent with size ranges found in samples from other oceans.

Sixty percent of the species were represented by females only. Three species, known only from below $2,000 \mathrm{~m}$, were represented by males and females in the same tows. The presence of spermatophore sacs on some females and the large number of juvenile stages indicate some reproduction is occurring at depth.

Available alternatives for the nutrition of deep-sea Copepoda are other zooplankton, organic aggregates, autochthonous unicellular organisms, organic matter transported downward, and detritus.

Four new species are described: Mimocalanus sulcifrons, Paivella naporai, Undinella gricei, and Zenkevitchiella tridentae, with systematic remarks for eight others, including two species (Aetideopsis retusa and Scolecthricella timida) not previously known from the Atlantic Ocean.
\end{abstract}

Contribution of the Graduate School of Oceanography, University of Rhode Island

Official publication date is handstamped in a limited number of initial copies and is recorded in the Institution's annual report, Smithsonian Year.

UNITED STATES GOVERNMENT PRINTING OFFICE WASHINGTON : 1970

For sale by the Superintendent of Documents, U.S. Government Printing Offec Washington, D.C. 20402 - Price 45 cents (Paper Cover) 


\section{Ellsworth H. Wheeler, fr. Atlantic Deep-Sea Calanoid Copepoda}

\section{Introduction}

Published accounts of deep-sea copepod species prior to 1948 have been reviewed and discussed by Sewell (1948). Unfortunately for purposes of comparison, few of the tows listed in Sewell's compilation were taken below $2,000 \mathrm{~m}$. Those few were not made with closing nets except for a series by Farran (1926) in the Bay of Biscay, using a vertical closing net without flowmeter and by Leavitt (1938) between Bermuda and the North American coast, using a horizontal closing net of coarse stramin, also lacking a flowmeter. Colman (1962) made two series of vertical, closingnet hauls in the Bay of Biscay but identified the specimens only to subclass.

The most notable report on Copepoda below 2,000 $\mathrm{m}$ in the Atlantic Ocean is by Grice and Hulsemann (1965), who analyzed the abundance, vertical occurrence, and taxonomy of calanoid copepods from the northeast Atlantic taken by personnel of the National Institute of Oceanography, Wormley, England, on board the R.R.S. Discovery II. The samples were collected with a vertical closing net incorporating a flowmeter and depth recorder.

The reports of Farran, Leavitt, Colman, and Grice and Hulsemann comprise the sum of published investigations in the Atlantic below 2,000 m with closing nets, and only the last named is truly quantitative.

\section{Methods}

Collegtions.-The opportunity to sample calanoid Copepoda from 2,000 to $4,000 \mathrm{~m}$ in the North and South Atlantic was provided by cruises 023 and 036

Ellsworth H. Wheeler, Jr., Department of Biological Sciences, Stanford University, Hopkins Marine Station, Pacific Grove, California 93950. of R.V. Trident, Graduate School of Oceanography, University of Rhode Island (Figure 1, Table 1). Included in Figure 1 are station locations for the work of Farran (1926) and Grice and Hulsemann (1965).

Tows 1 through 17 were taken with a modified Nansen vertical net of $70 \mathrm{~cm}$ diameter (NV-70). The net is similar to that used by Grice and Hulsemann (1967), having a flowmeter mounted within the mouth and a time-depth recorder (Benthos Manufacturing Company, North Falmouth, Massachusetts) attached to the weight below the plankton bucket. The depth at closure is estimated from the ascent speed of the net $(60 \mathrm{~m} / \mathrm{min})$, the descent speed of the messenger $(200$ $\mathrm{m} / \mathrm{min}$ ), the depth of the net when the messenger is released, and from the flowmeter reading and depth recording. This information indicated that most tows closed prematurely, probably due to the rolling of the ship, and a small catch resulted. For this reason a horizontal closing net was rigged.

For Tows 18 through 32, a large Clarke-Bumpus sampler (Yentsch, Grice and Hart, 1962) was used. The closed sampler was lowered vertically to about $2,000 \mathrm{~m}$, opened, lowered to $4,000 \mathrm{~m}$, and then towed at $3.7 \mathrm{~km} / \mathrm{hr}$ average speed for approximately two and one half hours before closing and vertical retrieval. With this technique the flowmeter indicated volumes ranging from 450 to $678 \mathrm{~m}^{3}$ were sampled. Timedepth recorder charts show sampling depth varied from 2,200 to $4,100 \mathrm{~m}$. With all tows, calanoid copepods were washed from the net and preserved in 5 percent buffered formalin.

IDENTIFICATION.-The identification procedure involved temporary staining of the exoskeleton with Poirrior's Blue and the removal and mounting of swimming legs and oral appendages. Drawings were made with a camera lucida, and total length in $\mathrm{mm}$ (anterior 
TABLE 1.-Collection data for adult calanoid copepod species (excluding contaminants) from $2000-4000 \mathrm{~m}$

\begin{tabular}{l|c|c|c|c|c|c|c}
\hline $\begin{array}{c}\text { Tow } \\
\text { No. }\end{array}$ & $\begin{array}{c}\text { Station } \\
\text { No. }\end{array}$ & Date & Latitude & Longitude & $\begin{array}{c}\text { Vol. } \\
\text { Sampled } \\
\left(\mathrm{m}^{3}\right)\end{array}$ & $\begin{array}{c}\text { Copepod } \\
\text { Species }\end{array}$ & Remarks \\
\hline
\end{tabular}

NANSEN VERTICAL NET (0.24 mm mesh aperture)

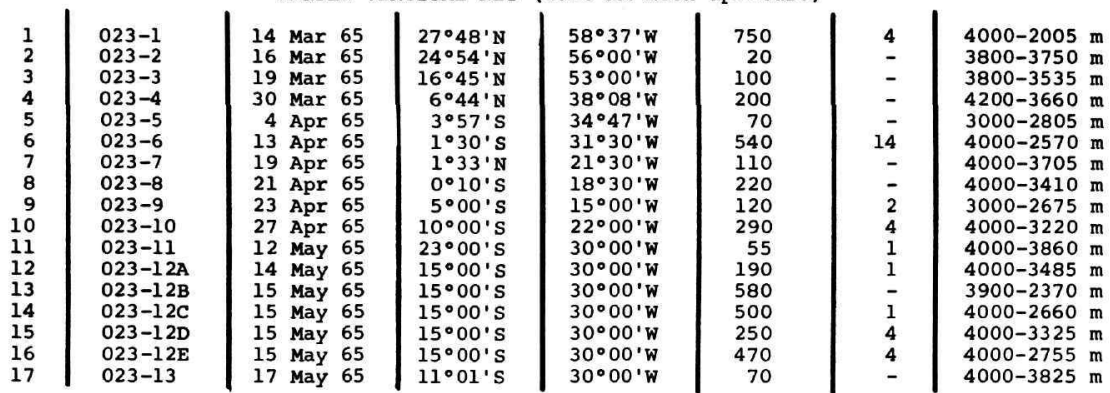

LARGE CLARKE-BUMPUS SAMPLER $(0.37 \mathrm{~mm}$ mesh aperture)

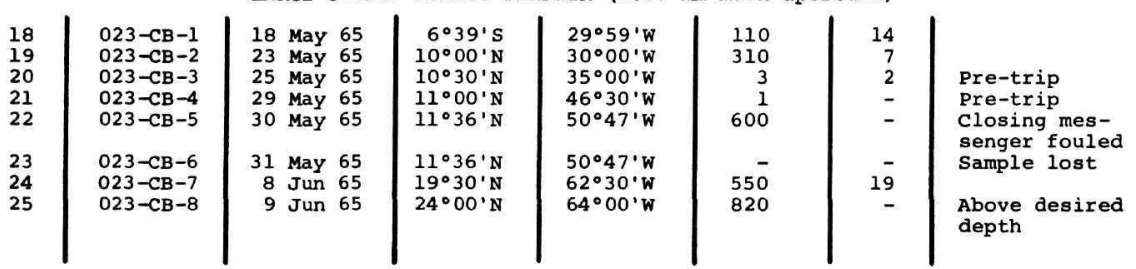

LARGE CLARKE-BUMPUS SAMPLER ( $0.12 \mathrm{~mm}$ mesh aperture)

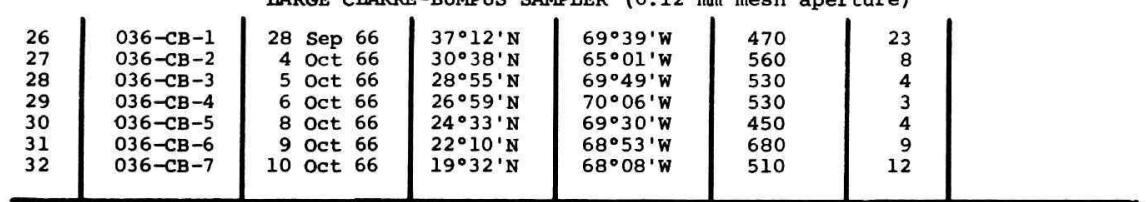

tip of cephalothorax to posterior end of caudal furcae) was measured with an ocular micrometer. Of 1,556 copepods examined, 553 (103 species) were adults and 1,003 were calanoid juveniles.

Contaminant SPEcies.-Grice and Hulsemann (1965) compared NV-70 hauls of varying length above $2,000 \mathrm{~m}$ with tows below this level and listed 16 species as probable contaminants in their nets below $1,000 \mathrm{~m}$. Their work in the Indian Ocean (Grice and Hulsemann, 1967) with a similar net added 26 species to the previous contaminant list, assuming no difference in vertical distributions of species between the two oceans. Recently, Grice and Hulsemann (1968) worked with the NV-70 net in an arrangement which allows the mouth to be closed while lowering. Their results indicate that shallow-water species are entrained as the open net descends vertically. This phenomenon would be common to all vertical nets low- ered in the open position and may explain the anomalous distributions found by Wolfenden (1911), Farran (1926), and noted by Sewell (1948, pp. 345-346).

The large Clarke-Bumpus sampler is also liable to contamination, which probably occurs via the narrow and varying (0-2 $\mathrm{mm}$ ) discrepancy between the closed shutter at the mouth of the net and the PVC barrel supporting the shutter and the flowmeter.

A conservative approach is used here in dealing with the contaminant problem. Listed below are 33 adult calanoid copepod species ( 310 individuals) that I consider to be contaminants below $2,000 \mathrm{~m}$ in all deep tows. A species is listed if so categorized by Grice and Hulsemann $(1965,1967)$ and if earlier reports of its vertical distribution (Leavitt, 1938; Sewell, 1948) support this decision. For example, Scolecithrix danae (Lubbock, 1856) is on the contaminant list of Grice and Hulsemann (1967) for NV-70 tows below 2,000 


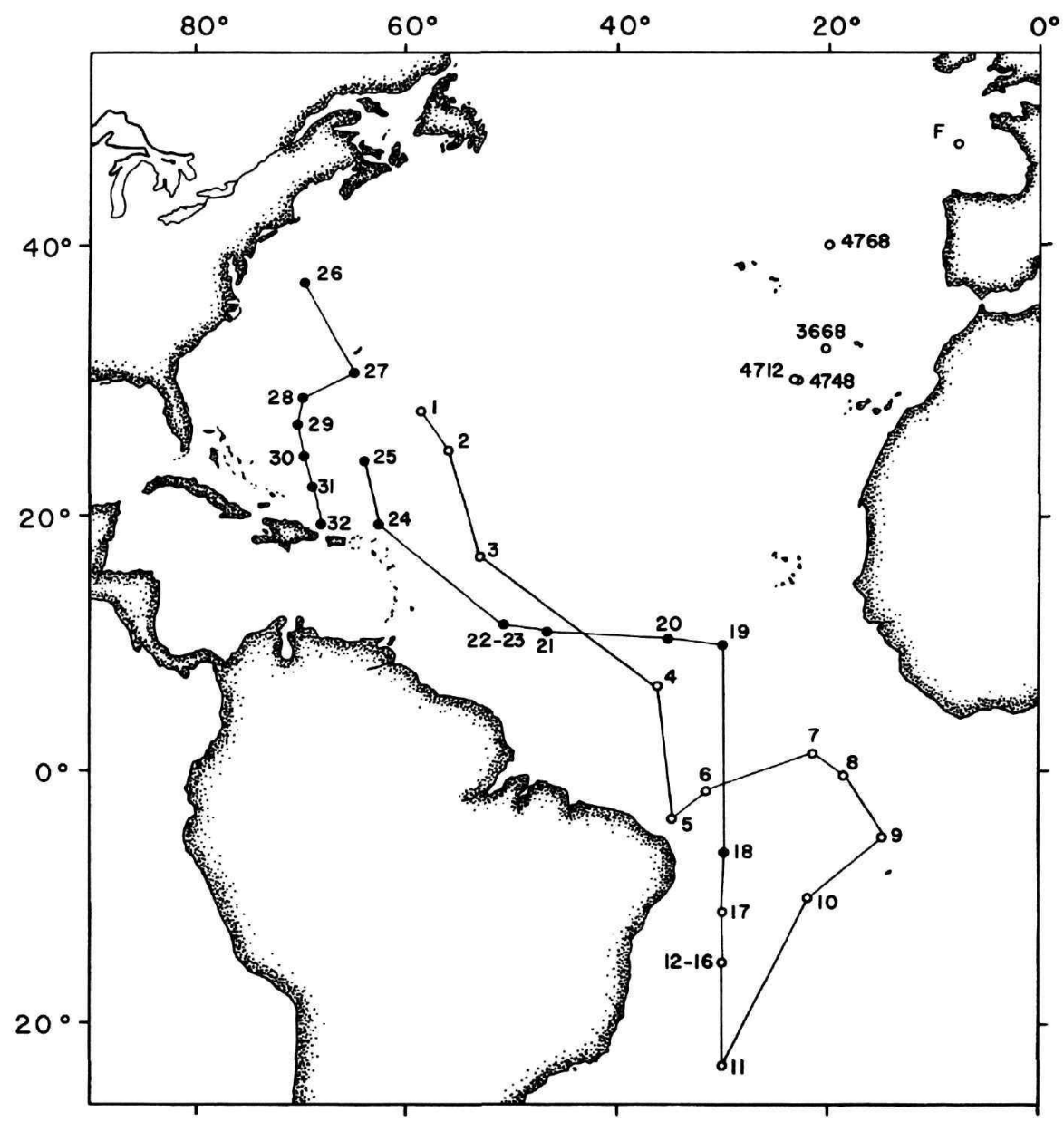

Figure 1.-Chart of tow locations. Open circles: vertical tows; closed circles: horizontal tows.

$m$ in the Indian Ocean but was taken in horizontal closing net tows by Leavitt (1938) at 2,800-3,000 $\mathrm{m}$ depth. $S$. danae is therefore not included in my list. Contaminant species for all tows are as follows:

\section{GALANDIDAE}

1. Calanus tenuicornis Dana, 1849

2. Nannocalanus minor (Claus, 1863)

3. Neocalanus gracilis (Dana, 1849)

4. Undinula vulgaris (Dana, 1849)

\section{EUCALANIDAE}

5. Mecynocera clausii Thompson, 1888

\section{PARACALANIDAE}

6. Acrocalanus longicornis Giesbrecht, 1888

7. Calocalanus contractus Farran, 1926
8. C. gracilis Tanaka, 1956

9. C. pavo (Dana, 1849)

10. C. pseudocontractus Bernard, 1958

11. C. styliremis Giesbrecht, 1888

12. C. tenuis Farran, 1926

13. Ischnocalanus plumulosus (Claus, 1863)

14. Paracalanus aculeatus Giesbrecht, 1888

15. P. denudatus Sewell, 1929

16. $P$. nanus Sars, 1907

17. P. parvus (Claus, 1863)

18. P. pygmaeus Claus, 1863

\section{PSEUDOCALANIDAE}

19. Clausocalanus arcuicornis (Dana, 1849)

20. C. furcatus (Brady, 1883)

21. C.paululus Farran, 1926 
22. C. pergens Farran, 1926

23. Ctenocalanus vanus Giesbrecht, 1888 AETIDEIDAE

24. Euaetideus acutus (Farran, 1929) SCOLECITHRICIDAE

25. Scaphocalanus curtus (Farran, 1929)

26. Scolecithrix bradyi Giesbrecht, 1888 GENTROPAGIDAE

27. Centropages violaceus (Claus, 1863) LUGICUTIIDAE

28. Lucicutia gaussae Grice, 1963

29. L. gemina Farran, 1926

\section{GANDACIIDAE}

30. Paracandacia bispinosa (Claus, 1863)

31. P. simplex (Giesbrecht, 1889)

ACARTIIDAE

32. Acartia danae Giesbrecht, 1889

33. A. negligens Dana, 1849

\section{The Population}

Abundance.-Numbers of adult copepods per 100 cubic meters for each station are given in Table 2. The results vary widely regardless of the volume of water sampled and the type of net used. The horizontal nets sampled more uniform volumes of water, but Tows 26 through 32 show values ranging from 0.6 to 10.0 adults $/ 100 \mathrm{~m}^{3}$. The fact that only certain vertical tows failed to catch any adults cannot be considered a sampling artifact since juvenile copepods were taken in these tows-that is, the net was functioning.

The abundance of adult copepods also varies among tows at the same location. Tows 12 through 16 were taken at $15^{\circ} 00^{\prime} \mathrm{S}, 30^{\circ} 00^{\prime} \mathrm{W}$. Values ranged from $0.0-$ 1.6 adults $/ 100 \mathrm{~m}^{3}$ with a mean of 0.6 When these data are considered with the results of other investigations, the scarcity of adult calanoid copepods from 2,000 to 4,000 $\mathrm{m}$ is apparent. Grice and Hulsemann (1965) found the maximum concentration of adults in the $10-50 \mathrm{~m}$ interval $\left(600\right.$ to $\left.2,200 / 100 \mathrm{~m}^{3}\right)$, with a secondary peak at 200 to $500 \mathrm{~m}\left(900 / 100 \mathrm{~m}^{3}\right)$ at the same stations where 10 to 30 adults $/ 100 \mathrm{~m}^{3}$ were found below 2,000 m. From a series of tows in the Bay of Biscay (labeled "F" on Figure 1), Farran's (1926) data, when converted to these units, show 140 to 160 specimens $/ 100 \mathrm{~m}^{3}$. These values represent adult calanoid and cyclopoid copepods as well as juvenile calanoids and cyclopoids and are therefore comparable.
TABLE 2.-Abundance of adult calanoid copepods (excluding contaminants) (See Table 1 for station data)

\begin{tabular}{|c|c|c|c|}
\hline $\begin{array}{l}\text { Tow } \\
\text { No. }\end{array}$ & Adults & $\begin{array}{l}\text { Adults } \\
/ 100 \mathrm{~m}^{3}\end{array}$ & $\begin{array}{c}\text { Vol. }\left(\mathrm{m}^{3}\right) \\
\text { Sampled }\end{array}$ \\
\hline $\begin{array}{r}1 \\
2 \\
3 \\
4 \\
5 \\
6 \\
7 \\
8 \\
9 \\
10 \\
11 \\
12 \\
13 \\
14 \\
15 \\
16 \\
17 \\
18 \\
19 \\
20 \\
21 \\
22 \\
23 \\
24 \\
25 \\
26 \\
27 \\
28 \\
29 \\
30 \\
31 \\
32\end{array}$ & 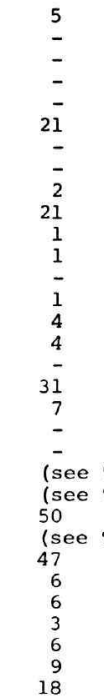 & $\begin{array}{r}0.7 \\
- \\
- \\
- \\
3.9 \\
- \\
- \\
1.7 \\
7.2 \\
1.8 \\
0.5 \\
- \\
0.2 \\
1.6 \\
0.9 \\
- \\
28.2 \\
2.3 \\
- \\
- \\
\text { Table } 1) \\
\text { Table } 1) \\
9.1 \\
\text { Table } 1) \\
10.0 \\
1.1 \\
1.1 \\
0.6 \\
1.3 \\
1.3 \\
3.5\end{array}$ & $\begin{array}{r}750 \\
20 \\
100 \\
200 \\
70 \\
540 \\
110 \\
220 \\
120 \\
290 \\
55 \\
190 \\
580 \\
500 \\
250 \\
470 \\
70 \\
110 \\
310 \\
3 \\
1\end{array}$ \\
\hline
\end{tabular}

Calanoid Copepoda were the most abundant metazoans in the samples. Their scarcity below $2,000 \mathrm{~m}$ emphasizes the small standing crop of other zooplankton.

SPECIES DIVERSITY.-Diversity indices (Fisher, Gorbet, and Williams, 1943; Margalef, 1958, and others) cannot be applied to the data of this investigation because of small sample size (Slobodkin, 1962; Hessler and Sanders, 1967). Information on the species to individuals relationship can be obtained from frequency distribution of species according to the number of adult individuals in each species (Figure 2). When all samples are pooled, 70 species (243 adults) are represented (solid bars). Most species occur as single individuals. A rapid decrease to an extreme of one species with 27 specimens characterizes the rest of the graph. The species to individuals ratio $(70 / 243)$ equals 0.29 . Included on the graph are data from N.I.O. samples $(2,000-4,000 \mathrm{~m}$; see Figure 1$)$ in the northeastern Atlantic (Grice and Hulsemann, 1966, unpublished Discovery II station data and list of species for Grice 


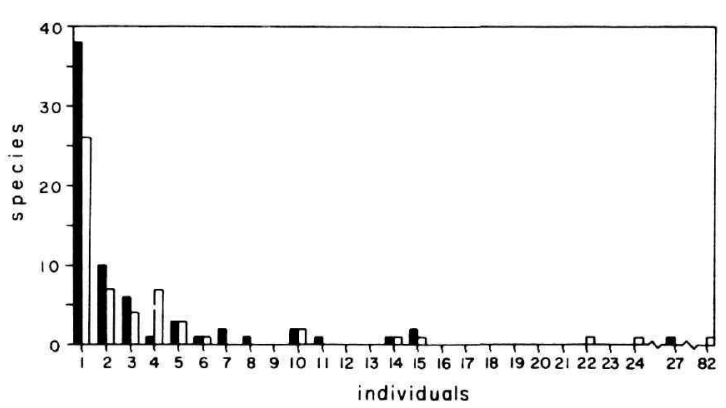

Frgure 2.-Frequency distribution: numbers of species arrayed according to number of adult individuals in each species (excluding contaminants). Solid bar: Wheeler; clear bar: Grice and Hulsemann (unpublished data from northeastern Atlantic).

and Hulsemann, 1965). Their results are similar: the diversity ratio $(55 / 278)$ equals 0.20 and most species are represented by a single individual. Their most abundant species (82 individuals) was $S$ pinocalanus abyssalis (including "var. pygmaeus") of which over half were taken in one haul (Station 3668). This copepod numbers 14 individuals in my tows, where the most abundant species is Lucicutia flavicornis with 27 individuals (considered a contaminant by Grice and Hulsemann).

After contaminant species are subtracted, Farran's (1926) data give a diversity ratio of 16 calanoid species to 154 individuals $(0.10)$.

To avoid confusion by pooling tows from the same latitude in different groups, Tows 26 and $27\left(37^{\circ} 12^{\prime} \mathrm{N}\right.$, $30^{\circ} 38^{\prime} \mathrm{N}$ ) can be combined with the N.I.O. data from $29^{\circ} 57^{\prime} \mathrm{N}$ to $40^{\circ} 03.5^{\prime} \mathrm{N}$. This grouping gives a diversity ratio of $0.34(59 / 176)$ for the pooled data of my investigation (all tows less numbers 26 and 27) and a ratio of $0.20(66 / 328)$ for the N.I.O. samples plus Tows 26 and 27. These ratios are plotted against latitude in Figure 3. The values indicate a trend of increasing diversity with decreasing latitude for adult calanoid Copepoda from 2,000-4,000 m, longitudinal differences notwithstanding.

Grice and Hulsemann's (1967) report does not include the numbers of individuals collected at each station. If we assume their sampling to be consistent, numbers of species taken between 2,000 and 4,000 m suggest this same change in diversity with latitude in the Indian Ocean:

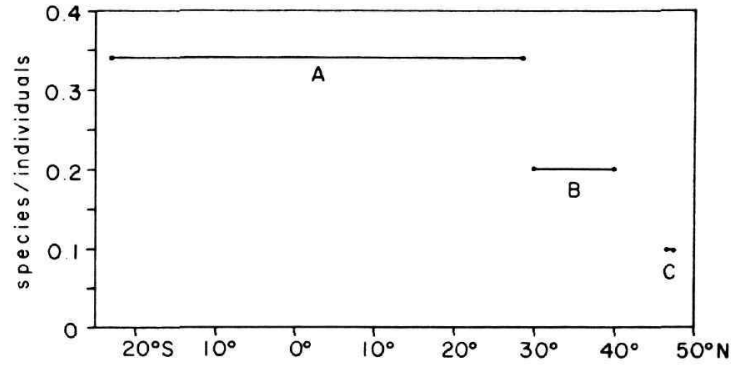

FIGURE 3.-Diversity ratios from pooled samples against latitude. A: Wheeler less Tows 26, 27; B: N.I.O. plus Tows 26, 27; G: Farran (1926). Length of horizontal line indicates latitudinal spread only.

$\begin{array}{cccc}\text { Station } & \text { Latitude } & \text { Depth }(m) & \text { Species } \\ & & & \\ 328 & 18^{\circ} 02^{\prime} \mathrm{N} & 3000-2000 & 18 \\ 332 & 10^{\circ} 04^{\prime} \mathrm{N} & 3000-2000 & 19 \\ 332 & 10^{\circ} 04^{\prime} \mathrm{N} & 4000-3000 & 8 \\ 334 & 06^{\circ} 01^{\prime} \mathrm{N} & 3000-1894 & 16 \\ 336 & 01^{\circ} 30^{\prime} \mathrm{N} & 3000-1940 & 21 \\ 338 & 02^{\circ} 38^{\prime} \mathrm{S} & 3000-2000 & 26 \\ 340 & 06^{\circ} 00^{\prime} \mathrm{S} & 2950-1990 & 28 \\ 342 & 10^{\circ} 07^{\prime} \mathrm{S} & 3000-1980 & 32 \\ 349 & 26^{\circ} 03^{\prime} \mathrm{S} & 3000-2000 & 8 \\ 349 & 26^{\circ} 03^{\prime} \mathrm{S} & 4000-3000 & 8 \\ 355 & 29^{\circ} 38^{\prime} \mathrm{S} & 3000-2000 & 3 \\ 355 & 29^{\circ} 38^{\prime} \mathrm{S} & 4000-3000 & 8\end{array}$

A similar trend exists for calanoids from Pacific surface waters (Brodsky, 1959, cited by Fischer, 1960) and for Copepoda and other zooplankton from shallower levels of the Atlantic (Grice and Hart, 1962).

Hypotheses for the causes of latitudinal gradients in species diversity (specifically, more species at low latitudes) have been reviewed by Pianka (1966). Each approach links changing diversity with another latitudinal gradient existing in the environment or faunal community: age of the community, environmental complexity, intensity of interspecific competition, or climatic stability and productivity. None of these hypotheses appear to apply to the pelagic deep sea because there is no evidence for an accompanying gradient in the environment. Nearer the surface such latitudinal gradients do exist, as do larger populations of copepods which vary in diversity. I believe species diversity in the deep sea is echoing that of upper levels, and that one must look to the upper strata as the major source of deep-living copepod species rather than hypothesizing a population which is largely endemic. 
SPECIES OCGURRENCE.-The species assemblage below $2,000 \mathrm{~m}$ is cosmopolitan. Table 3 lists the number of species from other regions which are in common with those from this investigation. Items 3 and 5 are not from closing net data but come from lists of species occurrence collated by the authors; items 5 and 6 are not limited to the $2,000-4,000 \mathrm{~m}$ level and are included for regional consideration.

Ten species from this investigation are listed below with indications of their occurrence in the regions and depths of Table 3. The number of cosmopolitan species could be doubled by including higher strata $(1,000$ $2,000 \mathrm{~m}$ ) of the northeastern Atlantic and Indian oceans.

\begin{tabular}{cl} 
Species & \multicolumn{1}{c}{$\begin{array}{c}\text { Region } \\
\text { (see Table 3) }\end{array}$} \\
calanus cultrifer & $2,3,4$ \\
calanus abyssalis & $1,2,3,4$ \\
gnus & $1,2,3,4,5,6$ \\
ocalanus brevicornis & $4,5,6$ \\
dia brevicauda & $3,4,5,6$ \\
princeps & $1,4,5$ \\
utia curta & $1,3,4$ \\
orhabdus compactus & $1,2,3,4$ \\
tilus longicornis & $2,3,4,5$ \\
& $1,4,5$
\end{tabular}

Exceptions to the general, vertical distribution of $1,000-4,000 \mathrm{~m}$ for these species and others are Foxtonia barbatula Hulsemann and Grice, 1963, and Temorites discoveryae Grice and Hulsemann, 1965. First described from the northeastern Atlantic, then reported from the Indian Ocean, in no case have these species

TABLE 3.-Number of species from other regions in common with this investigation

\begin{tabular}{|c|c|c|}
\hline Region & $\begin{array}{l}\text { Number } \\
\text { species } \\
\text { total }\end{array}$ & $\begin{array}{l}\text { Number } \\
\text { species } \\
\text { in common }\end{array}$ \\
\hline 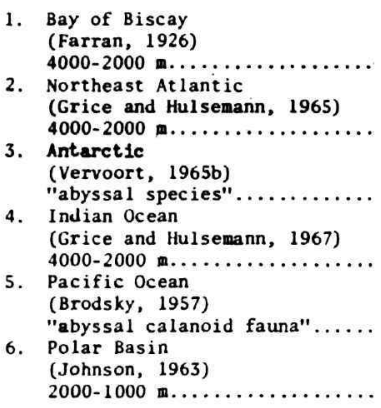 & 113 & 14 \\
\hline
\end{tabular}

been taken above $2,000 \mathrm{~m}$. Their occurrence appears to be widespread though restricted vertically. Both species occurred in my tows (see Taxonomy section).

Mean size.-Adult calanoid copepods (excluding contaminant species) averaged $2.14 \mathrm{~mm}$ total length. This result is consistent with mean lengths of northeast Atlantic, Indian Ocean, and tropical Pacific calanoid species (Grice and Hulsemann, 1965, 1967; Vinogradov, 1962).

Sex RATIOS.-Sixty percent of the species were represented by adult females only, with lesser percentages for categories of heterogeneous occurrence in males only. Many species of marine Copepoda are known and described from female specimens alone. Males may be present but escape sampling because they are shortlived, dying immediately after reproduction (Bogorov, 1939, cited by Mednikov, 1961). Hulsemann (1964) has suggested the female may devour the male after copulation, as is known to be the case with certain Arachnida and Insecta. Such a large intake of food could replenish reserves depleted during egg formation. There is no evidence for parthenogenesis among calanoid Copepoda as an explanation for the observed sex ratio (Charniaux-Cotton, 1960; Marshall and Orr, 1955; Vervoort, 1965b).

The spermatophore which is transferred from the male to the female during copulation is often lost during collection; a few, however, were seen on females from deep tows. This evidence (plus the large number of juvenile stages found) indicates that some reproduction is taking place below $2,000 \mathrm{~m}$. Foxtonia barbatula, Temorites discoveryae, and Zenkevitchiella atlantica - known only from below 2,000 m-are represented by both sexes (Grice and Hulsemann, 1965, 1967 ), and $F$. barbatula from my tows had female and male individuals in two of the five tows in which it occurred.

FOOD RELATIONSHIPS.-Available alternatives to the conventional primary producer as a source of nutrition for pelagic crustacean omnivores and carnivores of the deep sea include other zooplankton, organic aggregates (Riley, 1963), autochthonous unicellular organisms (Hentschel, 1936; Bernard, 1964; Fournier, 1966), organic matter transported downward by a "ladder of migrations" (Vinogradov, 1962), and detritus of plant or animal origin. Figure 4 illustrates these alternatives. The $2,000 \mathrm{~m}$ level does not imply a scale of depth from the surface downward but separates the region under consideration from the familiar producer- 


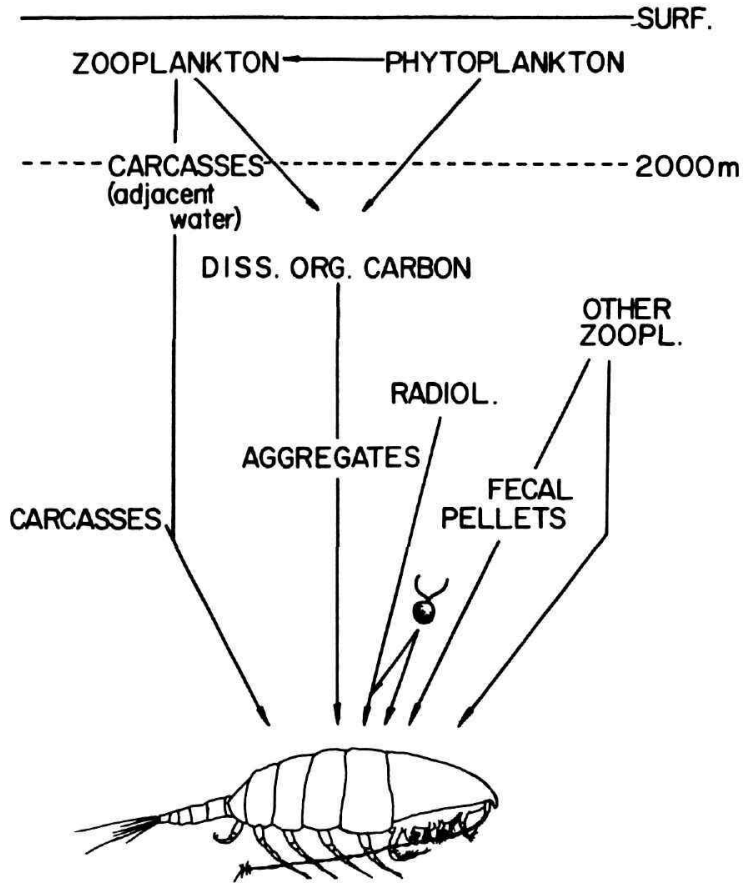

Figure 4.-Sources of food for deep-sea copepods. The flagellate represents unicellular organisms other than Radiolaria.

consumer relationships of upper waters. Two main routes are emphasized for the transfer of carbon from the surface to below $2,000 \mathrm{~m}$ : sinking of zooplankton carcasses from adjacent waters, a source presumably linked to surface waters by mortality during vertical migrations (Wheeler, 1967) ; and addition to the dissolved organic carbon pool via metabolic activity and autolysis. The line connecting "dissolved organic carbon" with "aggregates" is based on the hypothesis that adsorption of dissolved organic material onto organic aggregates occurs throughout the water column (Riley, Van Hemert, and Wangersky, 1965). Radiolarian fragments have been observed in gut-contents of deepsea copepods (Wheeler, 1967) as have the small cells described by Fournier (1966).

Until the effect of hydrostatic pressure on copepod metabolism is determined, and carbon requirements can be estimated, the adequacy of these suggested food sources is unknown.

\section{Taxonomy}

Four new species are described below, along with systematic remarks for eight others. The holotypes are deposited in the National Museum of Natural History collections. Two males, Spinocalanus species and Bathypontia species, which may be referable to known species are also figured. The 70 species found (243 adults, excluding contaminants) are listed in Table 4. Included in the list and discussion are two species (Aetideopsis retusa Grice and Hulsemann, 1967; Scolecithricella timida Tanaka, 1962) which are not previously known from the Atlantic Ocean.

In the discussion the first through the fifth pedigerous segments refer to those to which the first through fifth pairs of legs are attached. Size reference scales are in millimeters. Total length is measured from the anterior tip of the cephalothorax to the posterior end of the caudal furcae. Terminology used is that proposed by Gooding (1957).

\section{Mimocalanus sulcifrons, new species}

Figures 5-20

Occurrence.-Tow 30: 1 male $(2.02 \mathrm{~mm})$.

Diagnosis (male).-Prosome elongate, with cephalosome flaring laterally midway between front of head and anterior border of 1 st pedigerous segment. Lateral margin of 1st pedigerous segment minutely dentate. Fourth and 5th pedigerous segments fused. Posterolateral margins of 5 th pedigerous segment broadly rounded. Urosome of 5 subequal segments.

Anterior portion of cephalosome appears bilobed, indented dorsally with rounded, V-shaped groove, bearing fine setae on interior sides. Rostrum absent.

First antenna with 24 free segments; segments 2-8 adorned with horn-shaped esthetes. Antennae extend 1-2 segments beyond furcal rami. Basipod of 2nd antenna with 1 proximal and 2 distal setae. Exopod 7segmented; segments 3-6 each bearing 1 seta; segment 7 with 1 lateral seta and 3 strong terminal setae. Endopod is 2-segmented, the distal segment with 13 setae and a row of small spines along distolateral margin. Base of mandibular palp with 2 setae; endopod 2segmented, with 2 setae on 1st segment and 8 setae on terminal segment. Exopod 4-segmented, with a total of 6 setae. Gnathal lobe of mandible appears reduced, with 2 blunt teeth. First inner lobe of 1st maxilla reduced and devoid of spines or setae. Second and 3rd inner lobes bear 1 and 2 setae respectively; 2nd basal segment with row of 4 sharp spines on distal inner margin. Endopod with 9 setae; exopod with 10 setae. Second maxilla reduced, with 7 distinct lobes; proximal 
TABLE 4.-List of adult calanoid copepod species (excluding contaminants) and corresponding tow numbers (see Table 1)

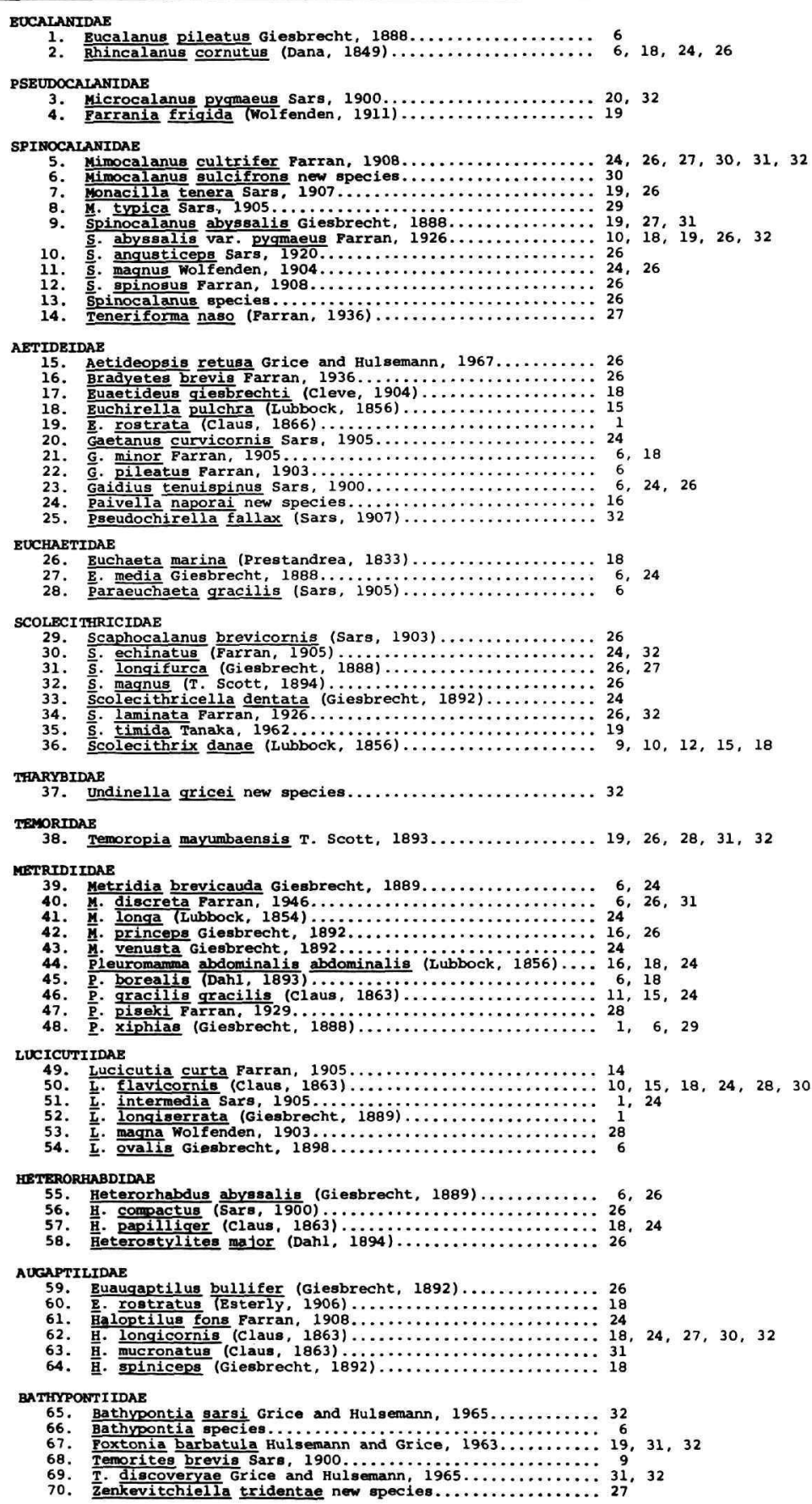


lobe without setae; remaining lobes with 2-3 setae each. Maxilliped with elongate basipodal segments, each with 1 distal seta. Anterior lateral margins of both segments of basipod with row of fine hairs on either side of their common articulation. Endopod is 5-segmented with a total of 19 setae.

Endopod of leg 1 unisegmental bearing an inner lobe, 1 subterminal, and 2 terminal setae. Second segment of basipod with several small spines on distolateral corner. First segment of exopod apparently without setae or spines. Remainder of exopod missing. Only the basipods and 1st segments of exopod and endopod of legs 2-4 remain on this specimen. Endopod segments without spines or setae; 1st segment of exopod with stout distolateral spine. First basipodal segments of pairs 2-4 with 1 inner seta. Fifth legs uniramous and 5-segmented, left leg slightly longer than right leg. Terminal segment of left leg ending in 2 small points, that of right leg in 1 small point. Holotype: USNM 122646.

Remarks.-This species differs from the generic description of Farran (1908, cited by Davis, 1949) in that the fourth and fifth pedigerous segments are fused rather than separate; the genus was established, however, on the basis of female specimens only. The male described here conforms most closely to the male of Mimocalanus nudus Farran, 1908, described by Grice and Hulsemann (1965) except for minor differences in the number of setae on the oral appendages, the fusion of the last two pedigerous segments on this species, and the unique configuration of the front of the cephalosome. The indentation on the head also distinguishes this species from the male of $M$. cultrifer Farran, 1908, first described by Tanaka (1956).

The males of $M$. inflatus Davis, 1949, and $M$. major Sars, 1920, have not been described. The former species is unique in having inflated endopodal segments on the swimming legs, whereas the latter is large $(4.20$ $\mathrm{mm}$ total length). The present species is not referable to either M. inflatus or M. major. Brodsky (1950) described $M$. distinctocephalus from females of north Pacific waters and Johnson (1963) reported three females from the Polar Basin. Brodsky's figures show no indentation on the cephalosome, nor is there additional evidence for considering my specimen to be the undescribed male of $M$. distinctocephalus, particularly in view of the absence of $M$. distinctocephalus from the Atlantic.

The species described above is here named Mimo- calanus sulcifrons for the peculiar structure of the anterior portion of the head.

\section{Monacilla typica Sars, 1905}

Figures 21-22

Occurrence.-Tow 29: 1 male $(1.01 \mathrm{~mm})$.

REMarks.-Sars (1924-1925) described the male $M$. typica from an individual of $1.90 \mathrm{~mm}$ total length. Farran and Vervoort (1951) gave a size range for the male of $1.60-2.30 \mathrm{~mm}$. The present specimen is smaller and differs from Sar's figures in that the endopod of the left fifth leg is more club-shaped than styliform and terminates in a small spine. The terminal spine of the right fifth leg is missing. Until additional males are found, this evidence is insufficient for erecting a new species.

\section{Spinocalanus sp. Johnson, 1963}

Figures 23-26

Occurrence.-Tow 26: 1 male $(1.66 \mathrm{~mm})$.

REMarks.-This male is similar to two males described by Johnson (1963) from the Polar Basin. His specimens, which he identified as "Spinocalanus ? male" were larger $(1.85 \mathrm{~mm})$ and differed from the usual genus description by having uniramous, asymmetrical fifth legs and by lacking spinules on the posterior surfaces of the swimming legs.

Tanaka (1956) described a similar species, $S$. longipes, from one male occurring in a $1,000-0 \mathrm{~m}$ vertical haul from Sagami Bay. The fifth legs were asymmetrical, but the exopod of the right fifth leg was shown with one segment.

Only the basipod segments of the elongate right fifth leg are present on this individual; the similarity, however, to Johnson's figures for his specimen is close. A full species description requires additional individuals.

Teneriforma naso (Farran, 1936)

Figures 27-28

Tanyrhinus naso Farran, 1936, pp. 86-87, fig. 4 - Grice and Hulsemann, 1965, p. 231, fig. 8.

Teneriforma naso Grice and Hulsemann, 1967, p. 22, figs. 36-38.

Occurrence.-Tow 27: 1 female $(1.20 \mathrm{~mm}) ; 1 \mathrm{~V}$ female $(1.05 \mathrm{~mm})$. Tow 29: $1 \mathrm{~V}$ female $(0.86 \mathrm{~mm})$. 
Remarks.-This rare copepod was first reported by Farran (1936) from outside the Great Barrier Reef where a single female was found between $600 \mathrm{~m}$ and the surface. Grice and Hulsemann (1965) reported the first Atlantic record with a female from $500-180 \mathrm{~m}$ and another from $3,000-2,000 \mathrm{~m}$ in the northeastern Atlantic, considering the latter individual a contaminant from higher levels in the deep, vertical tow. These authors (1967) found at least three additional specimens (including the previously undescribed male) in hauls of $2,000-750 \mathrm{~m}, 3,000-1,940 \mathrm{~m}$, and 2,000 $1,000 \mathrm{~m}$ from the Indian Ocean. Including the three individuals from my samples (taken in deep, horizontal tows), eight of the ten known specimens were taken in deep tows, justifying its designation as a deepsea form.

Aetideopsis retusa Grice and Hulsemann, 1967

Figures 29-30

Occurrence.-Tow 26: 1 female (2.25 mm).

ReMarks.-A prominent frontal organ, distinctly separate rostral rami, long first antennae, and a smaller total length distinguish this species from $A$. rostrata Sars, 1903, and $A$. multiserrata (Wolfenden, 1904). Described from the Indian Ocean, this is the first record of Aetideopsis retusa from the Atlantic and the second known specimen.

\section{Gaidius tenuispinus Sars, 1900}

\section{Figures 31-32}

Occurrence.-Tow 6: 1 female $(2.02 \mathrm{~mm})$. Tow 24: 1 female $(2.48 \mathrm{~mm})$. Tow 26: 1 male $(2.95$ $\mathrm{mm})$.

Remarks.-The individuals taken agree with specimens described from the North Atlantic (Vervoort, 1952) except for the larger total length of the male: $2.95 \mathrm{~mm}$ vs. $2.00 \mathrm{~mm}$. Males reported from the southern ocean (Vervoort, 1957), however, exceeded $3.00 \mathrm{~mm}$ in total length, indicating a wide variation for the species.

Illustrations of the male fifth legs are not numerous, and a detailed view is included here.
Paivella naporai, new species

Figures 33-48

Occurrence.-Tow 16: 1 female $(1.27 \mathrm{~mm})$.

Diagnosis (female).-Prosome elongate with cephalosome and 1st pedigerous segment, 4th and 5th pedigerous segments fused. Posterolateral margin of cephalothorax triangularly produced and pointed, overlapping genital segment by about one-third.

Urosome 4-segmented. Genital segment produced into 2 distinct protuberances extending ventrally and laterally, visible in dorsal view. Length of furcal rami twice the width.

Rostrum acutely double-pointed and ventrally directed. Frontal organ with 2 hairs visible in dorsal view. First antenna with 22 free segments reaching to middle of urosome; 8th and 9th, 24th and 25th segments fused. Basipod of 2nd antenna with 1 proximal and 2 distal setae. Exopod 7-segmented; segments 1 and 3-6 bearing 1 strong seta each, segment 2 with 2 setae, and segment 7 with 3 terminal setae. Endopod 2-segmented; 1st segment with 1 distal seta, 2nd segment with a total of 14 setae. Base of mandibular palp with 2 setae; endopod 2-segmented, with 1 large and 1 small seta on 1 st segment, 10 setae on terminal segment; exopod 5-segmented bearing 6 setae. Mandible blade with fine, sharply pointed teeth on broadly pointed bases in irregular rows. First inner lobe of 1 st maxilla with 9 spines and 4 setae; 2 nd inner lobe with 4 setae; 3rd inner lobe with 3 setae. Second basal segment with 5 setae; endopod with 11 setae and 11 setae on exopod. Outer lobe with 7 setae. Second maxilla 5lobed; 1st, 2nd, and 3rd lobes with 3 setae each and bearing fine spinules; 4 th lobe with 2 thin and 1 coarse seta; 5th lobe with 2 setae on either side of thickened, minutely dentate spine. Endopod 3-segmented with a total of 5 setae. Basipodal segments of maxilliped elongate; endopod 5-segmented.

Four pairs of swimming legs. Exopods 3-segmented; endopods of pairs 1 and 2 with 1 segment, pairs 3 and 4 with 3-segmented endopods. First basipod of pair 1 without spine on lateral margin. Pair 4 with 2 rows of stout spines on 1st basipod; distal row on thickened ridge. Terminal spines of pairs $2-4$ with strong, acute teeth on external margin. Holotype: USNM 122647.

Remarks.-In describing the genus Paivella, Vervoort (1965a) considered it to be intermediate between Aetideus Brady, 1883, and Snelliaetideus Ver- 
voort, 1949, as well as agreeing in certain aspects with Euaetideus Sars, 1925. The unique feature of the genus is the presence of 2 transverse rows of stout spines"teeth" according to Vervoort (1965a, p. 200) - on the posterior side of the first basipodal segment of the fourth legs.

This species agrees closely with the type and only species in the genus, Paivella inaciae Vervoort, 1965, except for minor differences in numbers of setae on the second antennae and oral appendages, and the presence of protuberances on the ventral aspect of the genital segment, similar to those described by Tanaka (1958) for certain Pareuchaeta species.

The profound structural difference in the genital segment provides for the establishment of a new species, Paivella naporai. It is dedicated to Dr. Theodore A. Napora, chief scientist on R.V. Trident cruise 023, who gave freely of his energy and time supporting the deep-sampling program of which the results are reported here.

\section{Scolecithricella timida Tanaka, 1962}

Figures 49-50

Occurrence.-Tow 19: 1 female (1.84 mm).

REMARKs.-Although larger in size $(1.84 \mathrm{~mm}$ vs. $1.52 \mathrm{~mm}$ total length) than the original specimens described by Tanaka (1962) from deep water of the northwestern Pacific, the female here agrees with his description and with the additional illustrations of Grice and Hulsemann (1967), except for the segmentation of the fifth legs. The present specimen shows clearly a 3-segmented, uniramous leg, whereas previous figures of this appendage suggest three but define only two segments. The placement of apical and lateral spines is similar in all cases.

Scolecithricella timida has not been previously recorded from the Atlantic.

\section{Undinella gricei, new species}

Figures 51-66

Occurrence.-Tow 32: 1 male $(1.88 \mathrm{~mm})$.

Diagnosis (male).-Prosome elongate with barely discernible separation between cephalosome and 1st pedigerous segment. Each lateral margin of 2nd and 3rd pedigerous segment with posteriorly directed point (not visible in dorsal view); 4th and 5 th pedigerous segments fused. Posterior margins of 5 th pedigerous segment with small protrusions adjacent to 1st segment of urosome. Fifth urosome segment one-sixth the length of preceding segment.

Rostrum prominent, extending ventrally as a broad, flattened structure with slight concavity between rostral rami. Margin of concavity with 2 small points. First antenna with 23 free segments, extending to 2nd urosome segment. Basipod of 2nd antenna with proximal tuft of fine, hairlike setae. Exopod 7-segmented with 1 strong seta on segments 2-5; segments 1 and 6 without setae; segment 7 with 2 terminal setae. Endopod 2segmented with 1 distal seta on 1st segment, 12 setae on 2nd segment. Mandibular palp with 2 strong spines on base; endopod 2-segmented with 1 setae on 1st, 9 setae on 2nd segment. Exopod 5-segmented with 5 setae. Gnathal lobe of mandible with 7 long teeth; outer 2 teeth bidentate. Mandibular blade with large, hirsute seta at inner edge and fine setae surrounding teeth. First maxilla with large, inner lobe bearing 13 strong spines; 2 remaining inner lobes with 2 and 3 setae. Second basal segment with 3 setae, endopod with 6 setae, outer lobe with 5 setae. Maxilliped with 5segmented endopod; basal segments elongate. Distal margin of 1st basipod segment with row of small hairs between seta and articulation of 2 nd segment.

Exopods of legs 1-4 with 3 segments. Endopod of pair 1 with 1 segment, pair 2 with 2 segments, pairs 3 and 4 with 3 segments. Fifth legs enlarged and modified. Second basal segment of each fifth leg tumid, right larger than left. Right 5th leg 2-segmented and uniramous. First segment elongate and flattened distally; terminal segment recurved inward, ending in a small, cup-shaped structure. Left 5 th leg biramous; exopod 2-segmented terminating in 2 processes; inner process with lobed configuration with row of fine hairs; outer process narrow, ending in small knob. Left 5th leg 3-segmented, 2nd segment with 4-lobed process. Terminal segment regular and cylindrical, ending in single knob. Holotype: USNM 122648.

REMarks.-The points on the second and third pedigerous segments and the configuration of the fifth legs distinguish this species from males of $U$. oblonga Sars, $1900, U$. brevipes Farran, 1908, and $U$. frontalis (Tanaka, 1937). The specimen differs from $U$. simplex (Wolfenden, 1906) by lacking points on the posterolateral corners of the fifth pedigerous segment and in 
the structure of the fifth legs. An Undinella male now being described by Grice (personal communication) appears closely allied in that the pedigerous segments are similar; differences here in the fifth legs, however, provide the basis for erecting a new species.

This copepod is named for Dr. George D. Grice of the Woods Hole Oceanographic Institution, who encouraged this work.

Temoropia mayumbaensis T. Scott, 1893

FIOURES 67-75

Occurrence.-Tow 19: 1 female $(0.56 \mathrm{~mm})$. Tow 26: 2 females $(0.76,0.75 \mathrm{~mm})$. Tow 28: 1 female $(0.86 \mathrm{~mm})$. Tow $31: 1$ female $(0.83 \mathrm{~mm})$. Tow 32: 1 female $(0.79 \mathrm{~mm})$.

Remarks.-Grice and Hulsemann (1965) considered this species a contaminant in vertical tows below $500 \mathrm{~m}$, presumably from earlier records such as Farran (1929), 120-0 m; Grice (1962), 150-1 m; and Vervoort (1965a), 100-0 m. Closing net tows by Farran (1908), however, contained T. mayumbaensis from $1,200 \mathrm{~m}$, and Grice and Hulsemann found eight individuals above $1,000 \mathrm{~m}$ compared to 46 specimens in tows closing below $1,000 \mathrm{~m}$ in the North Atlantic. Thirteen of their Indian Ocean samples out of 24 from below $1,000 \mathrm{~m}$ also contained the species. This evidence plus the six females taken in this collection with a fine-meshed horizontal net suggests that the vertical distribution is not restricted to the upper $500 \mathrm{~m}$.

According to Vervoort (1965a) T. mayumbaensis is a widely distributed species in which small, structural differences occur, suggesting morphological variation within the species or that closely related forms have been considered as one. Two types of fifth legs are seen on the females of this collection: "slender" and "thickened." The configurations illustrated are different enough to exclude flattening by the cover slip in the process of mounting the legs as an explanation. Accompanying the thickened feature of the legs is the presence of a spinelike process on the genital segment of the adult female (see Grice, 1962, p. 214, pl. 20, figs. 1-3). Individuals with slender fifth legs do not show this spine. Both types were found and are illustrated here. Examination of additional individuals may provide a basis for eventually separating these two types.
Metridia princeps Giesbrecht, 1889

Figure 76

OcCurRence.-Tow 16: 1 male $(7.65 \mathrm{~mm})$. Tow 24: $1 \mathrm{~V}$ male $(5.70 \mathrm{~mm})$. Tow $26: 1$ female $(7.42$ $\mathrm{mm}$ ).

Remarks.-Davis (1949) described a new species, Metridia bicornuta, from the northeastern Pacific Ocean on the basis of a pair of lateral points projecting from the side of the head in dorsal view. Sars (1924-1925, pl. 53, fig. 3) did not describe this feature but his figure indicates the structure on a lateral view of $M$. princeps. Grice and Hulsemann (personal communication) consider $M$. bicornuta to be referable to $M$. princeps. The lateral points illustrated here are most prominently seen on the copepodite stage $\mathrm{V}$ male from Tow 24.

\section{Bathypontia sarsi Grice and Hulsemann, 1965}

Figures 77-90

Bathypontia minor Sars, 1907, p. 27.

Bathypontia sarsi Grice and Hulsemann, 1965, p. 249.

Occurrence.-Tow 32: 1 male $(3.08 \mathrm{~mm})$.

ReMARKs.-Bathypontia minor Sars, 1907, was renamed $B$. sarsi by Grice and Hulsemann (1965) when the name became a junior homonym to Bathypontia minor (Wolfenden, 1906), an entirely different species. Sars described and illustrated the female in 1924-1925 but included one figure of the male fifth legs. A description of the important features of the male is given below with additional figures.

Cephalosome and 1st pedigerous segment are separate as are the 4 th and 5 th segments. Posterolateral corner of cephalothorax angular. Rostrum a single. elongate lobe. Urosome 5-segmented.

First antenna extends to 2nd urosome segment. Exopod of 2nd antenna 7-segmented; exopod slightly shorter and 2-segmented. Gnathal lobe of mandible with hirsute seta. Second maxilla with 7 terminal spines flattened for distal third of their length. Maxilliped more slender than 2nd maxilla.

Endopod of 1st leg with 2 segments; legs 2-4 with 3-segmented endopods. Exopod of right 2nd leg with elongate, external spine on 2nd segment which exceeds length of distal segment. Third leg with external spine on 2nd basipodal segment, extending beyond proximal segment of endopod. Fifth legs uniramous.

The fifth legs on this male differ from Sars' figure 
in that this specimen has a thickened, internal seta on the second basipodal segment of the right leg, where Sars shows no seta.

This species is most readily distinguished from $\boldsymbol{B}$. minor (Wolfenden, 1906) by the angular shape of the posterolateral corner of the cephalothorax.

\section{Bathypontia species}

Figures 91-93

Occurrence.-Tow 6: 1 female $(2.81 \mathrm{~mm}$ ).

Diagnosis (female).-Cephalosome and 1st pedigerous segment separate, 4th and 5th pedigerous segments separate. Posterolateral corner of cephalothorax a well-defined, rounded extension overlapping 1st third of genital segment. Rostrum a single, elongate lobe. Urosome 4-segmented.

First antenna with 24 free segments extending to genital segment. Gnathal lobe of mandible with hirsute seta. Second maxilla with 7 terminal spines, flattened for distal half of their length. Maxilliped more slender than 2nd maxilla.

Endopod of 1st leg 2-segmented; pairs 2-4 with 3segmented endopod. Fifth legs uniramous, symmetrical. Each ramus ending in 2 spines; internal spine dentate, exceeding terminal spine in length.

Remarks.-While the general appearance, size, rostrum, mandible, and fifth legs are closely similar to Bathypontia sarsi Grice and Hulsemann, 1965, the protruded lateral corners of the fifth segment of the cephalothorax are not figured on any Bathypontia species for which the female has been described. Grice and Hulsemann (1967) described a new male, $\boldsymbol{B}$. regalis, from the Indian Ocean, for which this may be the female; the gnathal lobe, however, is closer in appearance to that of $B$. sarsi.

The specimen is in poor condition, lacking the exopods of the second to fourth legs. It is therefore assigned to the genus Bathypontia Sars, 1905, until additional females are taken.

Temorites discoveryae Grice and Hulsemann, 1965

FigURES 94-96

OcGurrence.-Tow 27: 1 copepodite $(0.49 \mathrm{~mm})$. Tow $31: 1$ male $(0.64 \mathrm{~mm}) ; 1$ copepodite $(0.41 \mathrm{~mm})$. Tow 32: 2 females $(0.56-0.64 \mathrm{~mm})$.

REMARKs. The sex and juvenile stage of the copepodites taken in Tows 27 and 31 could not be determined.
Fifth legs were not present, suggesting no further advancement than stage IV; total length measurements support this estimate.

The large female $(0.64 \mathrm{~mm})$ from Tow 32 differs from the original diagnosis of the species in that the distal segment of the fifth legs has two terminal spines in addition to one on the inner lateral margin near the midpoint of the segment. The second female ( 0.56 $\mathrm{mm}$ ) conforms to the original description of Grice and Hulsemann. Both sets of fifth legs are figured here.

\section{Foxtonia barbatula Hulsemann and Grice, 1963}

\section{Figure 97}

Ocgurrence.-Tow 19: 1 female $(1.20 \mathrm{~mm}) ; 1$ IV male $(0.98 \mathrm{~mm})$. Tow $25: 1$ female $(1.20 \mathrm{~mm})$. Tow 27: $1 \mathrm{IV}$ male $(0.94 \mathrm{~mm})$. Tow $31: 1$ female $(1.35 \mathrm{~mm})$; $1 \mathrm{IV}$ male $(1.01 \mathrm{~mm})$. Tow $32: 2 \mathrm{fe}-$ males $(1.20-0.90 \mathrm{~mm}) ; 1 \mathrm{~V}$ female $(1.12 \mathrm{~mm})$.

Remarks. - This unique species was first taken in the northeastern Atlantic in vertical tows below 2,000 m (Hulsemann and Grice, 1963). These authors (1967) also reported it from three deep samples in the Indian Ocean. Figured here is the small adult female from Tow 32 near Puerto Rico. The adult male has not yet been taken.

\section{Zenkevitchiella tridentae, new species}

Figures 98-109

Occurrence.-Tow 27: 1 female $(0.79 \mathrm{~mm})$.

Diagnosis (female).-Prosome ovoid, cephalothorax separate from 1st pedigerous segment. Fourth and 5 th pedigerous segments separate, with posterolateral corners of 5 th segment broadly rounded. Urosome 4-segmented; genital segment with ventral, spinelike protrusions.

Rostrum with 2 long filaments, not visible in dorsal view. Anterior and posterior lips of mouth prominent and visible in lateral and ventral view. First antennae missing. Exopod of 2nd antenna with 1st segment inflated along outer margin and bearing a small point distally; remaining segments (presumably 4) broken off. Endopod 2-segmented with 12 setae on 2nd segment. Mandibular palp with 2 setae on basal segment. Exopod 4-segmented with 3 terminal setae and 1 seta each on 3 preceding segments. Endopod 2-segmented, 
the 1 st bearing 3 setae, the 2 nd with 9 setae. Mandible blade with 1 sharp tooth, 2 bidentate teeth; lateral margin of blade with row of small spines terminating in 2 longer spines. First maxilla with 7 spines on 1st inner lobe; 2 nd inner lobe with 3 setae; 3 rd inner lobe with 1 seta. Second basal segment with 1 seta; endopod absent; exopod with 5 long setae. Outer lobe without setae. Second maxilla with 1 st 4 lobes bearing 4 , 2,2 , and 3 setae of which one on 4th lobe is strong. Fifth lobe and terminal setae broken off. Maxilliped with large columnar 1st segment; remaining segments (probably 6) missing.

First 4 pairs of legs with 3-segmented exopods. Pair 1 with 2-segmented endopods; 1st segment with enlarged external margin and 1 internal seta. Second segment with row of fine hairs on external margin. Endopods of pairs 2-4 with only 1st segment remaining. Second basal segment of pair 3 with distolateral spinelike protrusion. Fifth legs biramous and symmetrical with 3-segmented exopod. First 2 segments of exopod with small spines on distal, external margin; terminal segment with 3 spines. Internal margin of 2 nd segment with 1 large, thick seta. Fifth leg with endopod of 1 seg- ment ending in 2 short spines. Holotype: USNM 122649.

REMARKS.-Although certain segments of the second antennae, second maxillae, maxillipeds, and second through fourth legs are missing from this specimen, it can be placed in the genus Zenkevitchiella Brodsky.

This female is readily distinguished from $Z$. abyssalis Brodsky, 1955 , by its small size $(0.79 \mathrm{~mm}$ vs. $2.37 \mathrm{~mm})$, by the presence of a small spine on the second basal segment of the third leg, and by the large, thick setae on the second segment of the exopod of the fifth leg. The spinelike structures on the ventral side of the genital segment figured here do not exist on $Z$. atlantica Grice and Hulsemann, 1965. In addition, $Z$. atlantica has only two segments in the exopod of the fifth leg, and the one-segmented endopods are bulbous without terminal spines.

The remaining species in the genus, $Z$. crass $a$ Grice and Hulsemann, 1967, was established for one male from the Indian Ocean, and the female has yet to be described; a comparison of second antennae, feeding appendages, and first legs, however, shows fundamental differences between this species and $Z$. crassa:

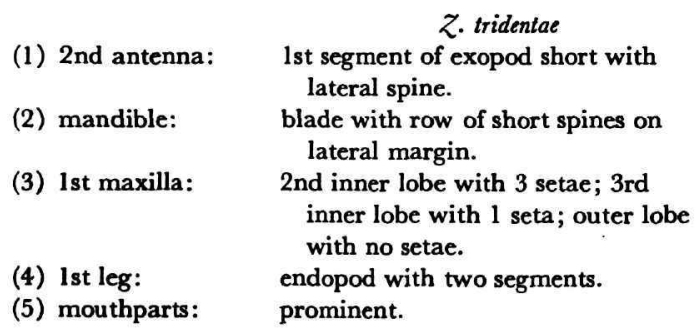

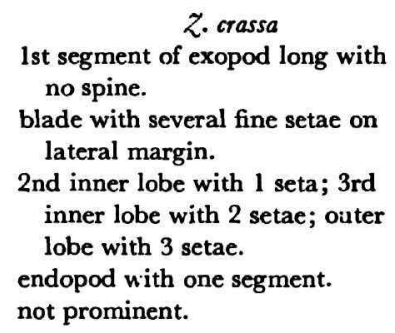

The evidence above does not permit the identification of the present female as $Z$. crassa. It is therefore named Zenkevitchiella tridentae, while it is realized that a final description requires the examination of additional specimens. The species is named for the R.V. Trident, of the Graduate School of Oceanography, University of Rhode Island, on which the copepod was taken.

\section{Literature Cited}

Bernard, F.

1964. Le Nannoplankton en Zone Aphotique des mers Chaudes. Pelagos, 2:1-32.

Bogorov, B. G.

1939. Sex Ratio in Marine Copepoda. Doklady Akademii nauk SSSR, 23:705-708.
Brodsky, K. A.

1950. Calanoida of the Far Eastern Seas and Polar Basin of the USSR. Keys to the Fauna of the USSR, Zoological Institute of the Academy of Sciences of the USSR, 335:1-442. Israel Program for Scientific Translations, number 1884.

1959. Concerning Phylogenetic Relationships of Several Species of Calanus (Copepoda) of the Northern and Southern Hemispheres. Zoologicheskii zhurnal, Akademii nauk SSSR, 338:1537-1552.

Charniaux-Cotton, $\mathrm{H}$.

1960. Sex Determination, pages 411-447. In T. H. Waterman (editor), The Physiology of Crustacea, volume 1. Academic Press, New York.

Colman, J. S.

1962. A Note on Deep Plankton in the Bay of Biscay. Rapport et procès-verbaux des réunions. Conseil Permanent International pour l'Exploration de la Mer, 153:207-210. 
Davis, C. C.

1949. The Pelagic Copepoda of the Northeastern Pacific Ocean. University of Washington Publications in Biology, 14:1-118.

Farran, G. P.

1908. Second Report on the Copepoda of the Irish Atlantic Slope. Scientific Investigations of the Fisheries Branch for Ireland, 1906, part 2, 104 pages.

1926. Biscayan Plankton Collected During a Cruise of H.M.S. Research, 1900: Part 14. The Copepoda. Journal of the Linnaean Society (Zoology), $36: 219-310$.

1929. Copepoda. Natural History Report. British Antarctic Terra Nova Expedition (Zoology), 8(3): 203-306.

1936. Copepoda. Scientific Reports of the Great Barrier Reef Expedition, 5(3): 73-142.

Farran, G. P., and W. Vervoort

1951. Copepoda. Suborder Calanoida. Family Spinocalanidae. Genera Mimocalanus and Monacilla. Zooplankton Sheet, Conseil Permanent International pour l'Exploration de la Mer, 40:1-4.

Fischer, A. G.

1960. Latitudinal Variation in Organic Diversity. Evolution, 14:64-81.

Fisher, R. A., A. S. Corbet, and C. B. Williams

1943. The Relation Between the Number of Species and the Number of Individuals in a Random Sample of an Animal Population. Journal of Animal Ecology, 12:42-58.

Fournier, R. O.

1966. North Atlantic Deep-Sea Fertility. Science, 153 (3741) : 1250-1252.

Gooding, R. U.

1957. On Some Copepoda from Plymouth, Mainly Associated with Invertebrates, Including Three New Species. Journal of the Marine Biological Association of the United Kingdom, 36:195-221.

Grice, G. D.

1962. Calanoid Copepods from Equatorial Waters on the Pacific Ocean. United States Fish and Wildlife Service. Fisheries Bulletin, 186, 61:167-246.

Grice, G. D., and A. D. Hart

1962. The Abundance, Seasonal Occurrence and Distribution of the Epizooplankton Between New York and Bermuda. Ecological Monographs, 32:287309.

Grice, G. D., and K. Hulsemann

1965. Abundance, Vertical Distribution and Taxonomy of Calanoid Copepods at Selected Stations in the Northeast Atlantic. Journal of Zoology, 146(2): 213-262.

1967. Bathypelagic Calanoid Copepods of the Western Indian Ocean. Proceedings of the United States National Museum, 122(3583):1-67.

1968. Contamination in Nansen-Type Vertical Plankton Nets and a Method To Prevent It. Deep-Sea Research, 15:229-233.
Hentschel, E.

1936. Allgemeine Biologie des Süd-atlantischen Ozeans. Das Pelagial der unteren Wasserschichten. Meteor Expedition, 6:1-344.

Hessler, R. R., and H. L. Sanders

1967. Faunal Diversity in the Deep Sea. Deep-Sea Research, 14:65-78.

Hulsemann, $\mathrm{K}$.

1964. A Moustached Copepod. Oceanus, 11:8-9.

Johnson, M. W.

1963. Zooplankton Collections from the High Polar Basin with Special Reference to the Copepoda. Limnology and Oceanography, 8:89-102.

Leavitt, B. B.

1938. The Quantitative Vertical Distribution of Macrozooplankton in the Atlantic Ocean Basin. Biological Bulletin, 74:376-394.

Margalef, $\mathbf{R}$.

1958. Temporal Succession and Spatial Heterogeneity in Phytoplankton, pages 323-349. In A. A. BuzzatiTraverso (editor), Perspectives in Marine Biology. University of California Press.

Marshall, S. M., and A. P. Orr

1955. The Biology of a Marine Copepod. Oliver and Boyd, Edinburgh. 188 pages.

Mednikov, B. $\mathbf{M}$.

1961. On the Sex Ratio in Deep Water Calanoida. Crustaceana, 3:105-109.

Pianka, E. R.

1966. Latitudinal Gradients in Species Diversity: a $\mathbf{R e}$ view of Concepts. American Naturalist, 100:33-46.

Riley, G. A.

1963. Organic Aggregates in Seawater and the Dynamics of Their Formation and Utilization. Limnology and Oceanography, 8:372-381.

Riley, G. A., D. Van Hemert, and P. J. Wangersky

1965. Organic Aggregates in Surface and Deep Waters of the Sargasso Sea. Limnology and Oceanography, $10: 354-363$

Sars, G. O.

1907. Notes Supplémentaires sur les Calanoides de la Princesse Alice (corrections et additions). Bulletin de l'Institut oceanographique de Monaco, 101: 27.

1924-25. Copépods, Particuliérement Bathypélagiques Provenant des Campagnes Scientifiques du Prince Albert ler de Monaco. Résultats des Campagnes Scientifiques. Text (1925), 69:408 atlas (1924), 127 plates.

Sewell, R. B. S.

1948. The Free-Swimming Planktonic Copepoda: Geographical Distribution. Scientific Reports. John Musray Expedition, 1933-34, 8(3):317-592.

Slobodkin, L. B.

1962. Growth and Regulation of Animal Populations. Holt, Rinehart, and Winston, New York, 184 pages. 
Tanaka, $O$.

1956. The Pelagic Copepods of the Izu Region, Middle Japan. Systematic Account II: Families Paracalanidae and Pseudocalanidae. Publications of the Seto Marine Biological Laboratory, 5(3):367-406.

1958. The Pelagic Copepods of the Izu Region. Middle Japan. Systematic Account V: Family Euchaetidae. Publications of the Seto Marine Biological Laboratory, 6(3):327-367.

1962. The Pelagic Copcpods of the Izu Region, Middle Japan. Systematic Account VIII: Family Scolecithricidae (part 2). Publications of the Seto Marine Biological Laboratory, 10(1):35-90.

Vervoort, W.

1952. Copepoda. Suborder Calanoida. Family Aetideidae. Genus Gaidius. Zooplankton Sheet, Conseil Permanent International pour l'Exploration de la Mer, 45: $1-4$.

1957. Copepods from Antarctic and Sub-Antarctic Plankton Samples. British Australian New Zealand Antarctic Research Expedition, Report Series B, 3:1-160.

1965a. Pelagic Copepoda. Atlantide Report, 8(2):9-216. 1965b. Notes on the Biogeography and Ecology of FreeLiving, Marine Copepoda. Monographie Biologicae, 15:381-400.

Vinogradov, M. E

1962. Feeding of the Deep-Sea Zooplankton. Rapport et Procès-verbaux des Réunions. Conseil Permanent International pour l'Exploration de la Mer, $153: 114-119$.

Wheeler, E. H., Jr.

1967. Copepod Detritus in the Deep Sea. Limnology and Oceanography, 12:697-702.

Wolfenden, R. N.

1911. Die marinen Copepoden der Deutschen SüdpolarExpedition 1901-1903, II: Die pelagischen Copepoden der Westwinddrift und des Südlichen Eismeers. In Deutsche Südpolar-Expedition, 12 (Zoology 4): 181-380.

Yentsch, C. S., G. D. Grice, and A. D. Hart

1962. Some Opening-Closing Devices for Plankton Nets Operated by Pressure, Electrical and Mechanical Action. Rapport et Procès-verbaux des Réunions. Conseil Permanent International pour l'Exploration de la Mer, 153:59-65. 


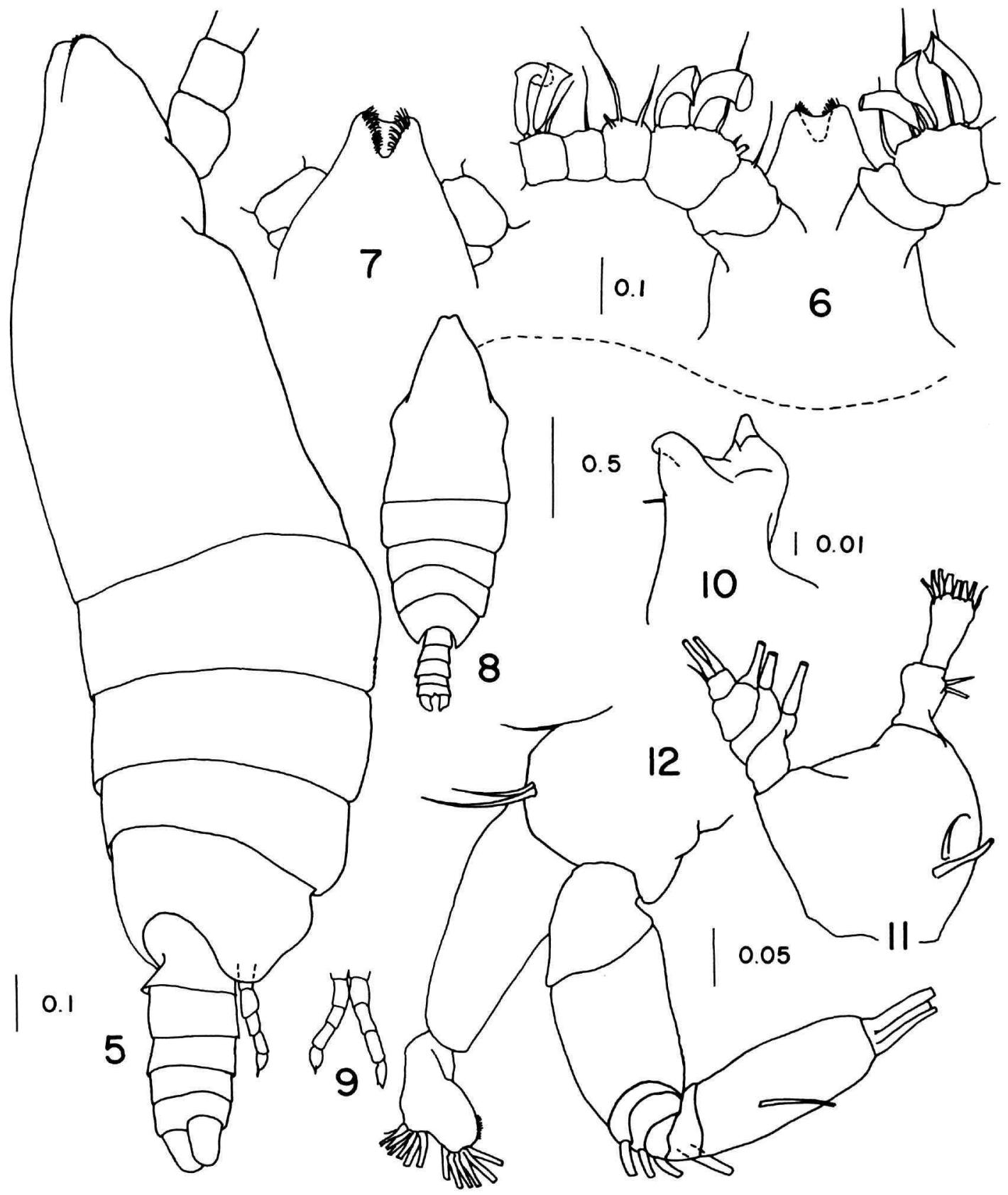

Figures 5-12.-Mimocalanus sulcifrons, new species, male: 5, adult, lateral view; 6, anterior end of head, ventral view ; 7 , anterior end of head, dorsal view; 8 , adult, dorsal view; 9 , male fifth legs; 10 , gnathal lobe of mandible; 11 , mandibular palp; 12 , second antenna. 


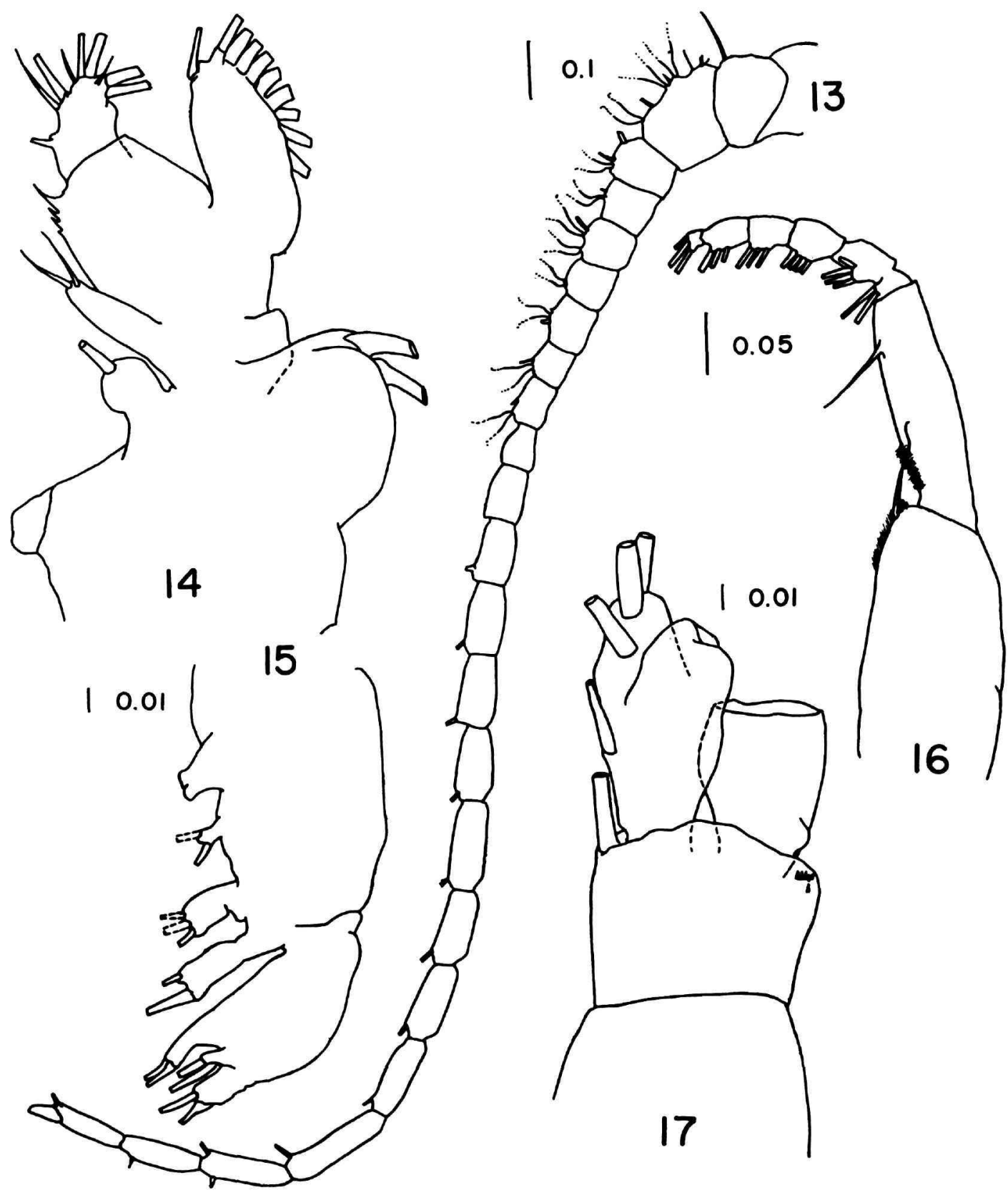

Figures 13-17.-Mimocalanus sulcifrons, new species, male: 13, first antenna; 14, first maxilla; 15, second maxilla; 16 , maxilliped; 17, first leg, last 2 exopod segments missing. 


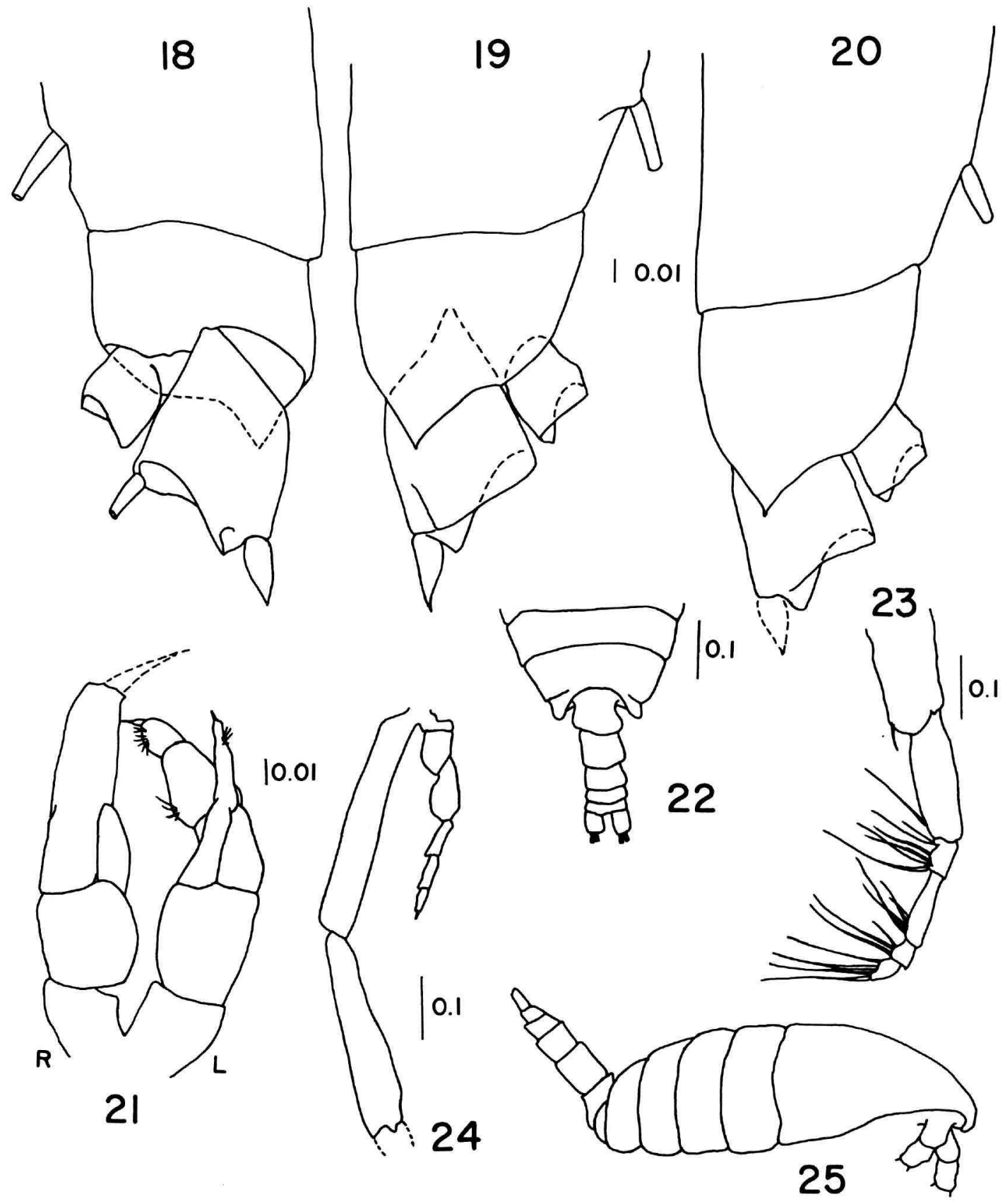

Figures 18-25.-Mimocalanus sulcifrons, new species, male: 18, second leg, rest of endopod and exopod missing; 19, third leg, rest of endopod and exopod missing; 20, fourth leg, rest of endopod and exopod missing. Monacilla typica, male: 21, fifth legs, terminal spine on right exopod missing; 22, posterior half of prosome, urosome, dorsal view. Spinocalanus species, male: 23 , maxilliped; 24 , fifth legs, terminal segments of right fifth leg missing; 25 , adult male, lateral view. 


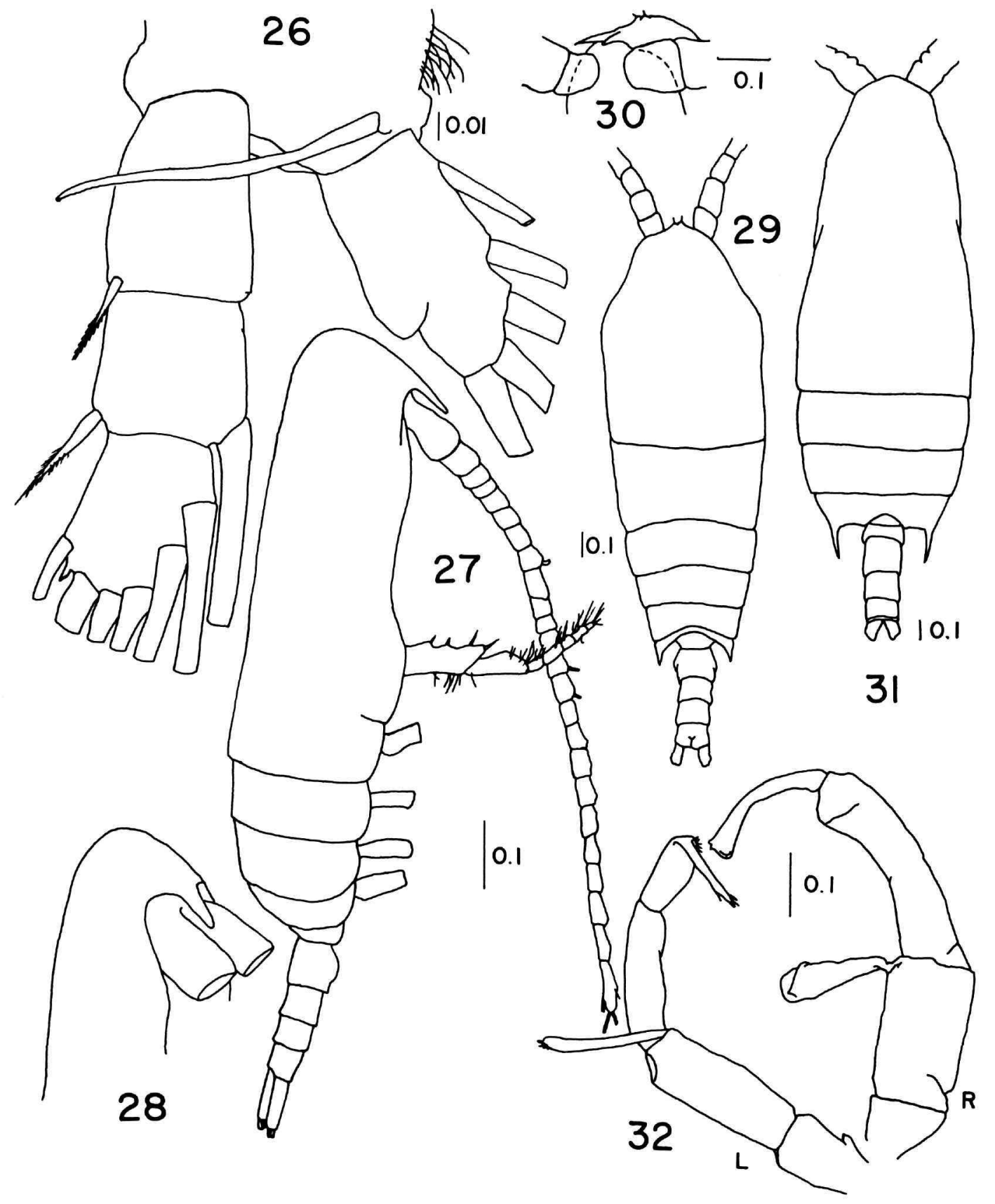

FigUres 26-32.-Spinocalanus species, male: 26, first leg. Teneriforma naso, female: 27, adult, lateral view; 28, anterior portion of head. Aetideopsis retusa, female: 29 adult, dorsal view; 30, anterior portion of head, ventral view. Gaidius tenuispinus, male: 31, adult, dorsal view; 32 , fifth legs. 

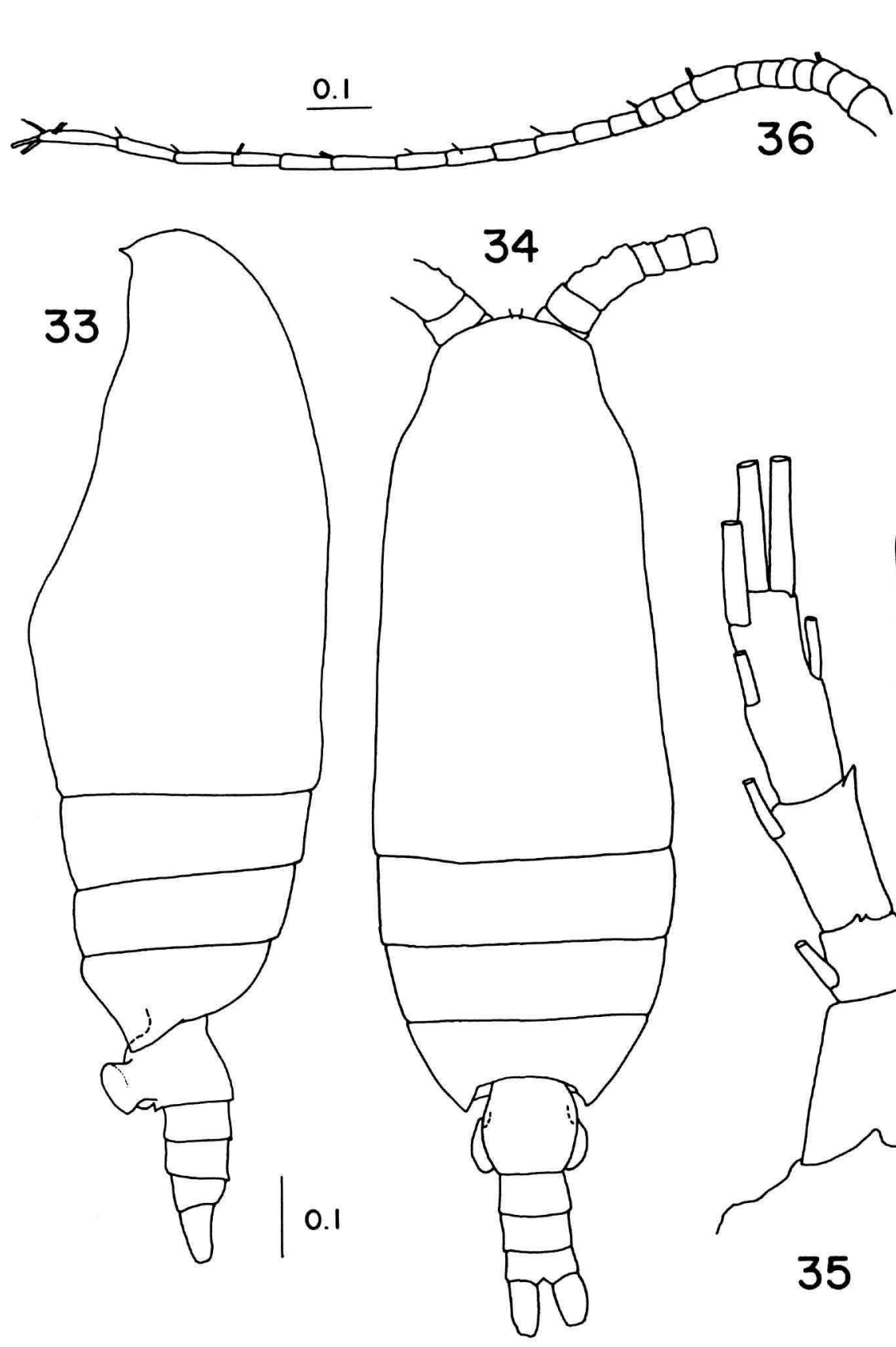

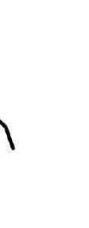




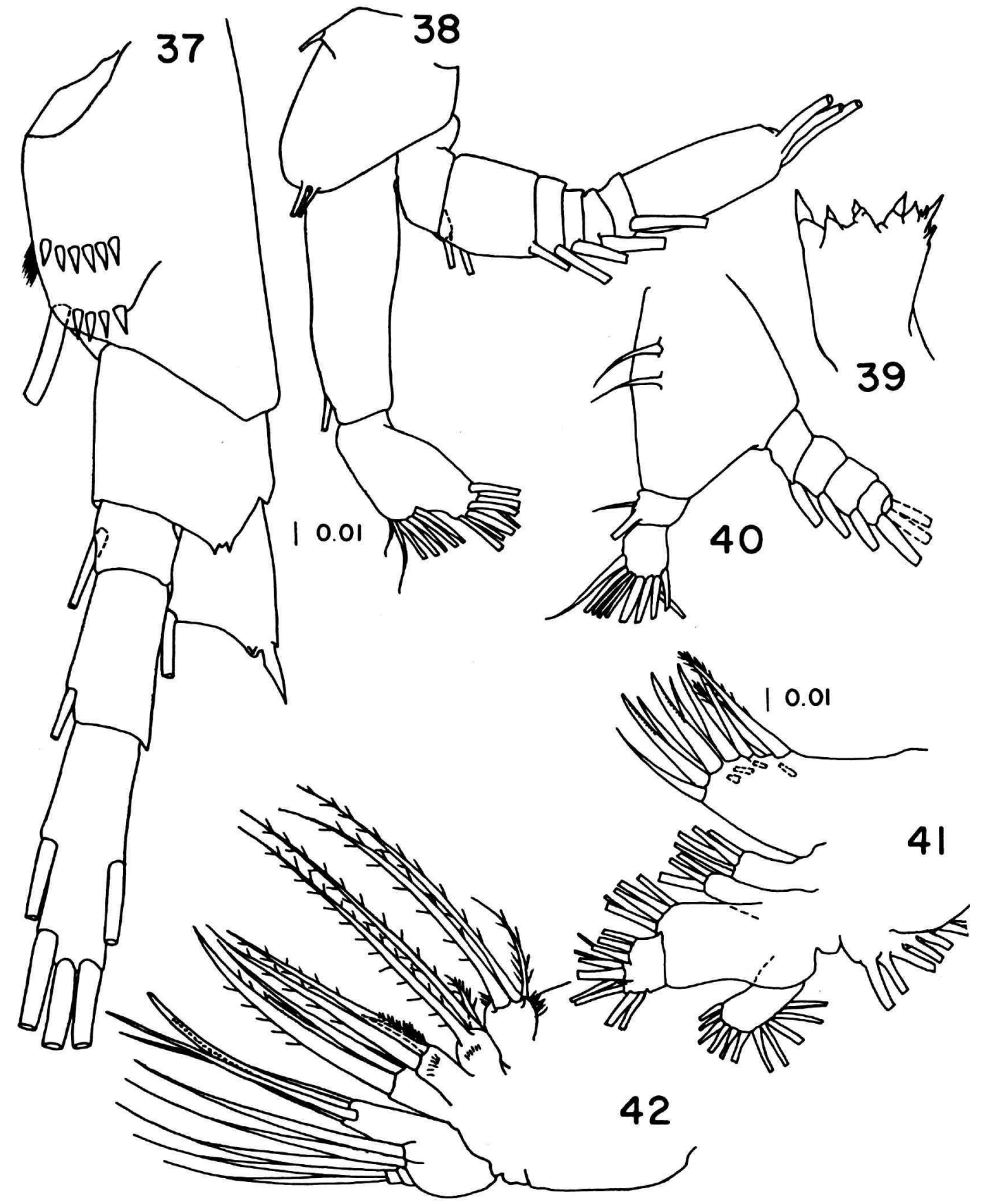

Figures 37-42.-Paivella naporai, new species, female: 37, fourth leg, last 2 segments of exopod omitted; 38 , second antenna ; 39 , gnathal lobe of mandible; 40, mandibular palp; 41, first maxilla; 42 , second maxilla. 


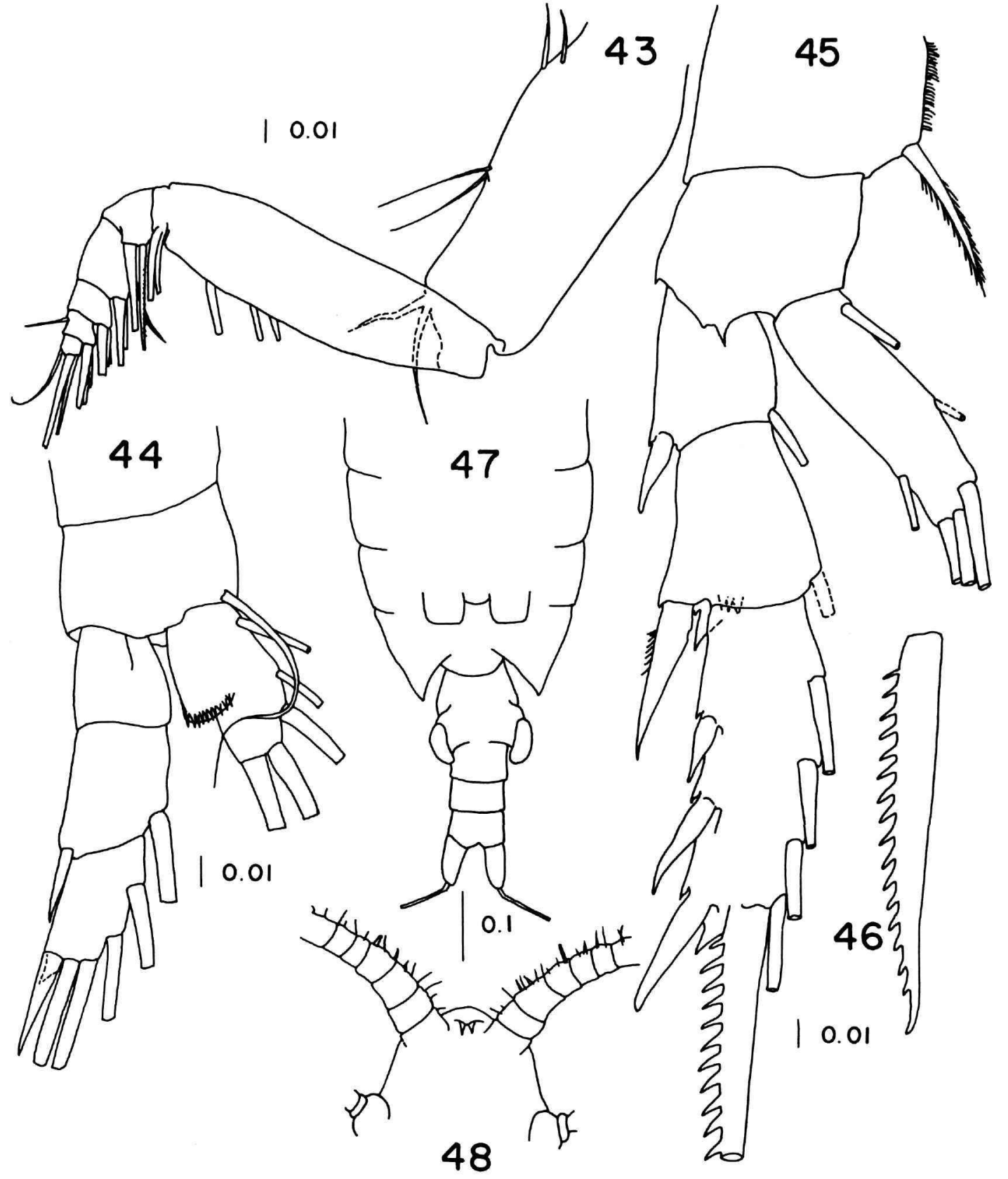

Figures 43-48.-Paivella naporai, new species, female: 43, maxilliped; 44, first leg; 45, second leg; 46 , complete terminal spine, second leg; 47 , posterior portion of prosome, urosome, ventral view; 48 , anterior portion of head, ventral view. 


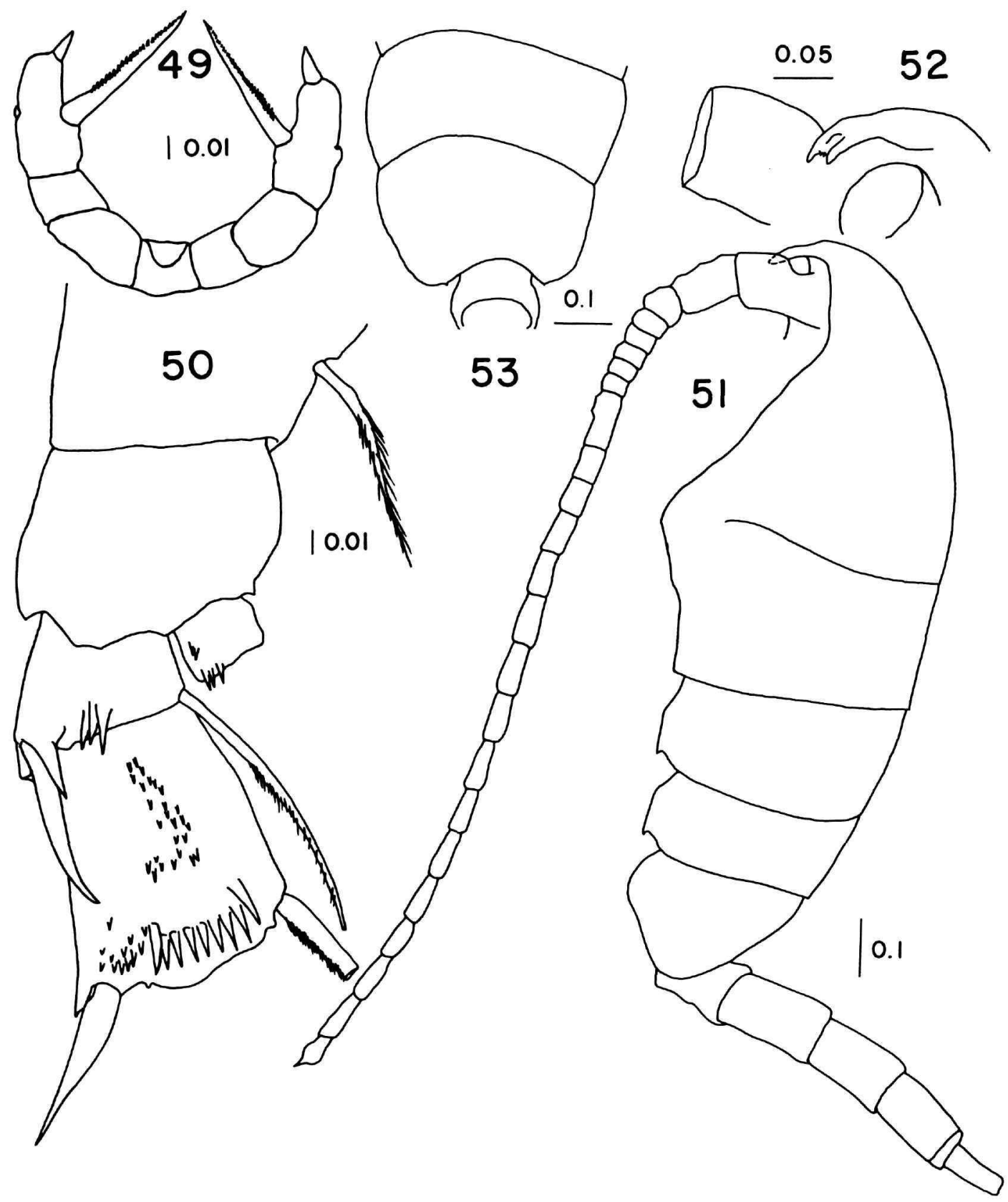

Figures 49-53. Scolecithricella timida, female: 49, fifth legs; 50, second leg, segments 2, 3 of endopod and segment 3 of exopod missing. Undinella gricei, new species, male: 51, adult, lateral view ; 52 , rostrum ; 53 , posterior portion of cephalothorax, dorsal view. 

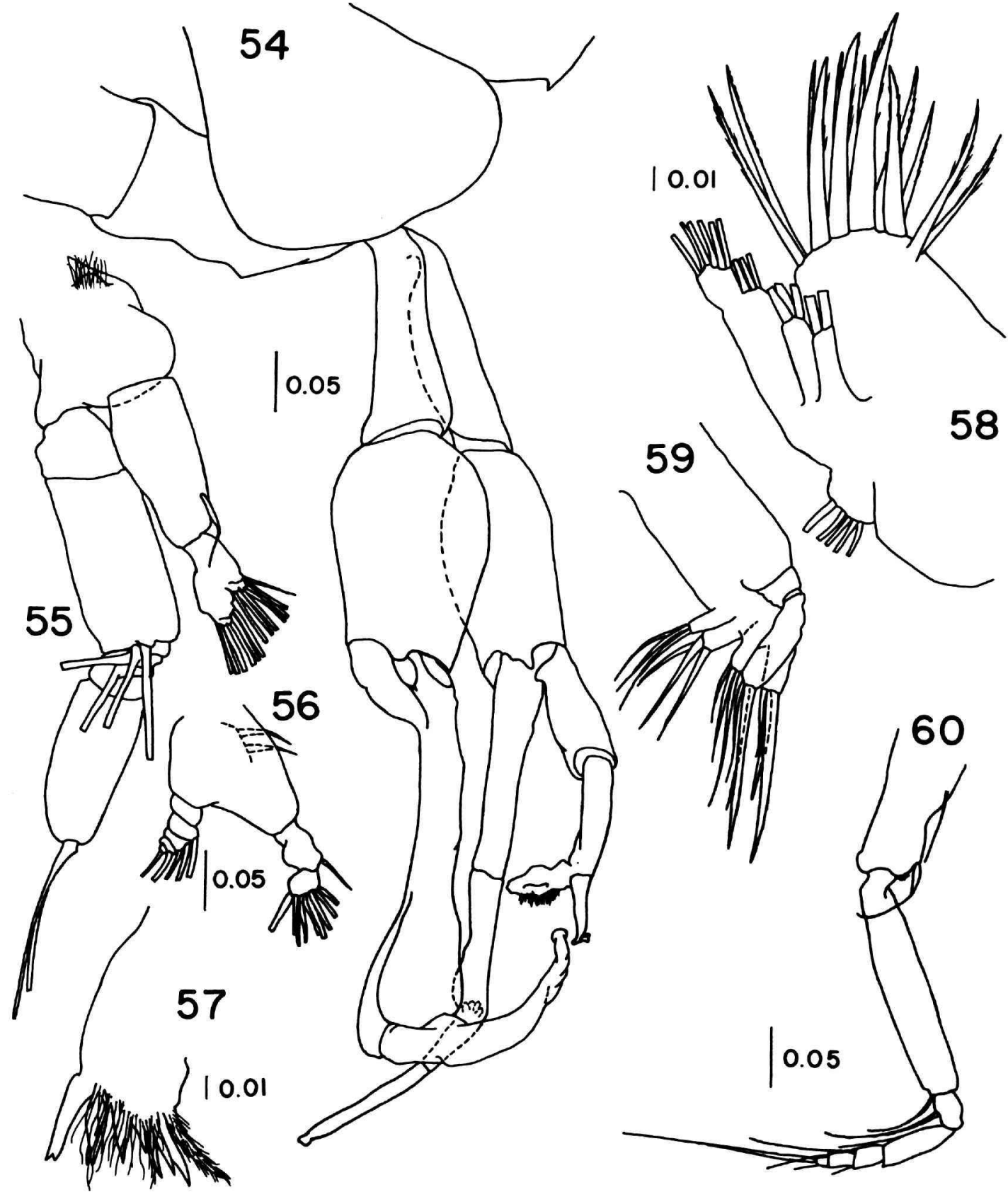

Figures 54-60.-Undinella gricei, new species, male: 54, last pedigerous segment and fifth legs, lateral view; 55 , second antenna; 56 , mandibular palp; 57 , gnathal lobe of mandible; 58 , first maxilla ; 59, second maxilla; 60 , maxilliped. 


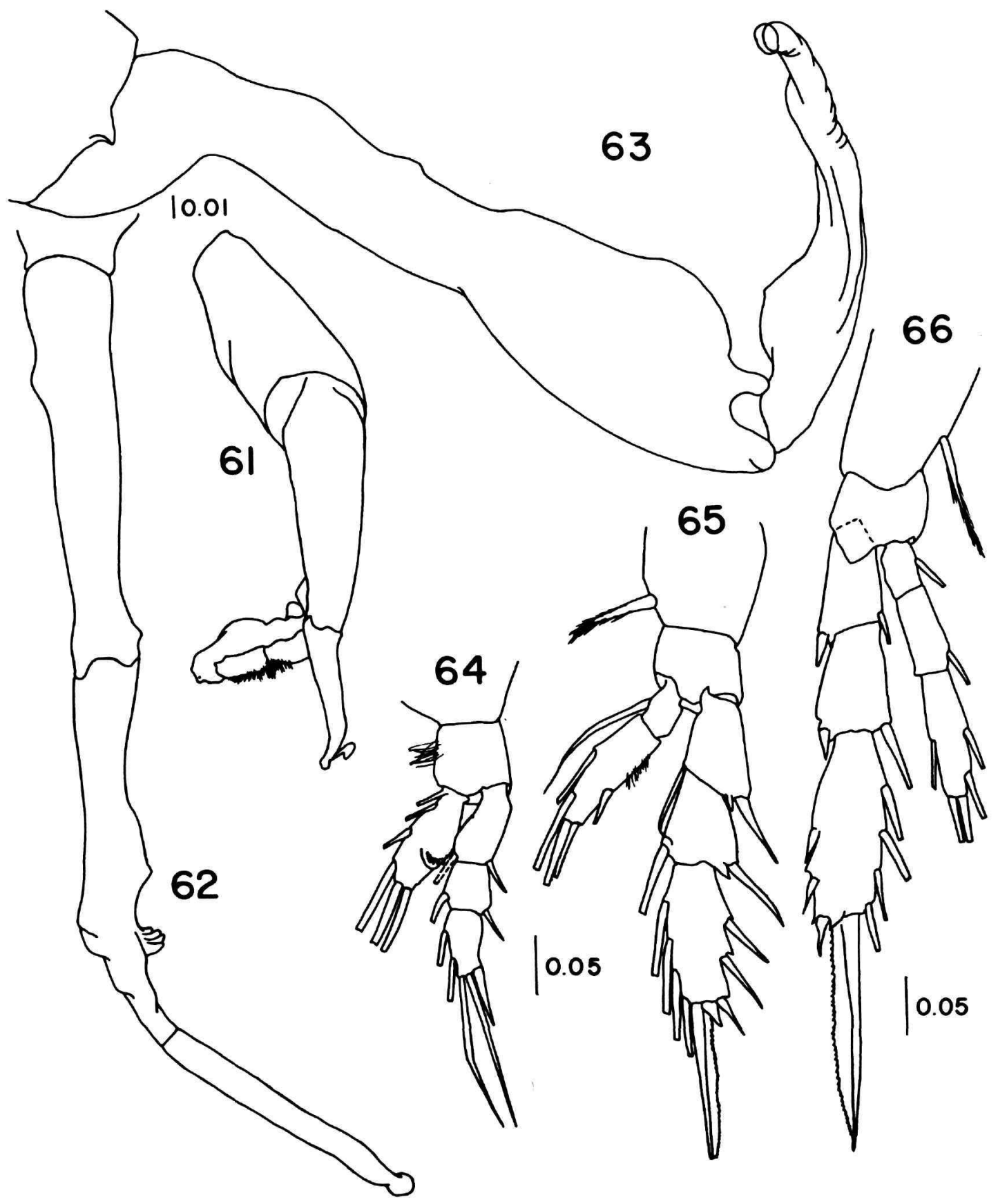

Frgures 61-66.-Undinella gricei, new species, male: 61, exopod of left fifth leg; 62, endopod of left fifth leg; 63 , right fifth leg; 64 , first leg; 65 , second leg; 66 , fourth leg. 


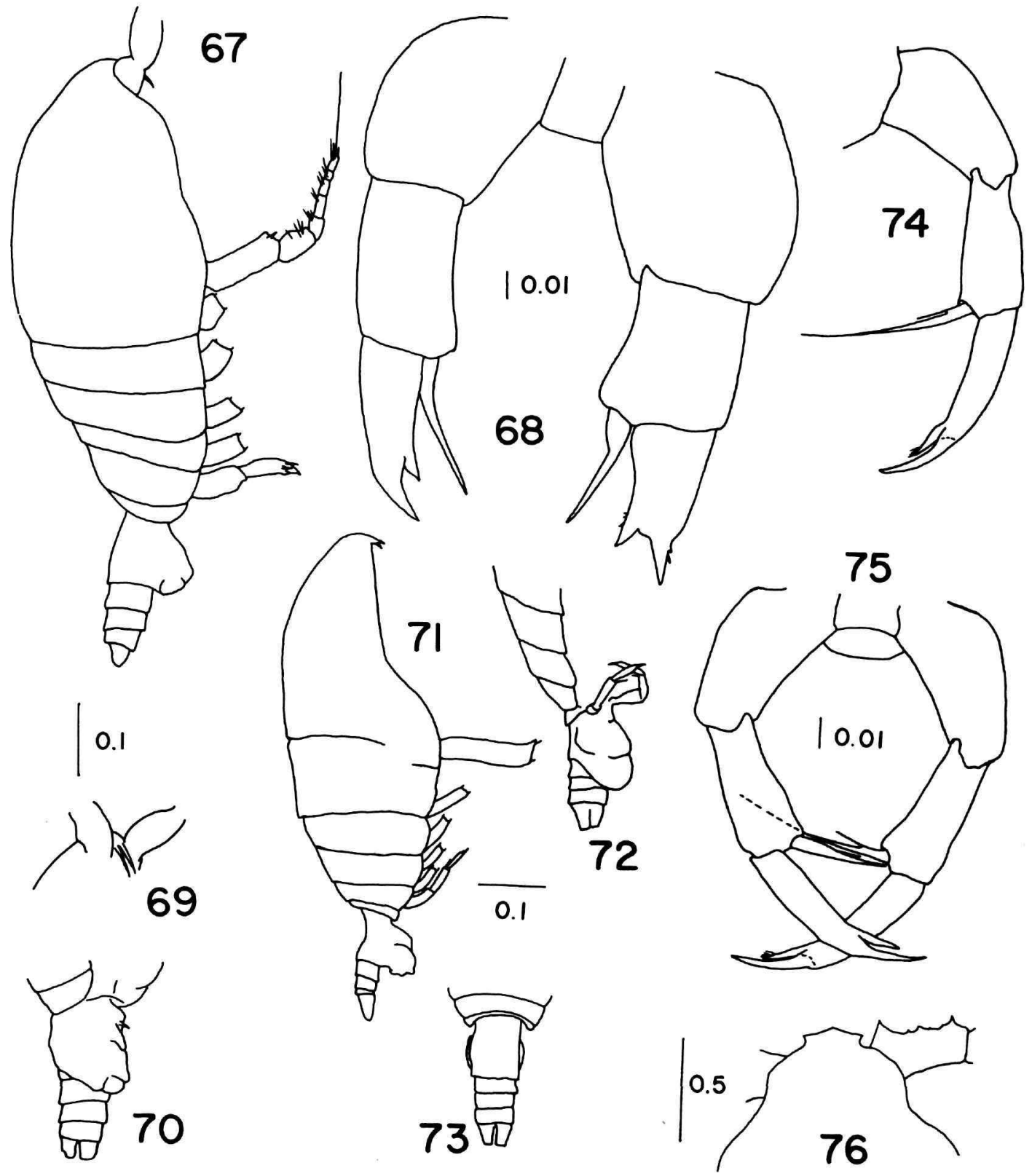

FIGUREs 67-76.-Temoropia mayumbaensis, female with "thickened" fifth legs: 67, adult, lateral view; 68 , fifth legs, "thickened" type; 69 , rostrum; 70 , urosome, three-quarter ventral view. Temoropia mayumbaensis, female with "slender" fifth legs: 71, adult, lateral view; 72, urosome and fifth legs; 73, urosome, dorsal view; 74, right fifth leg; 75, fifth legs. Metridia princeps, juvenile: 76, anterior portion of head, dorsal view. 


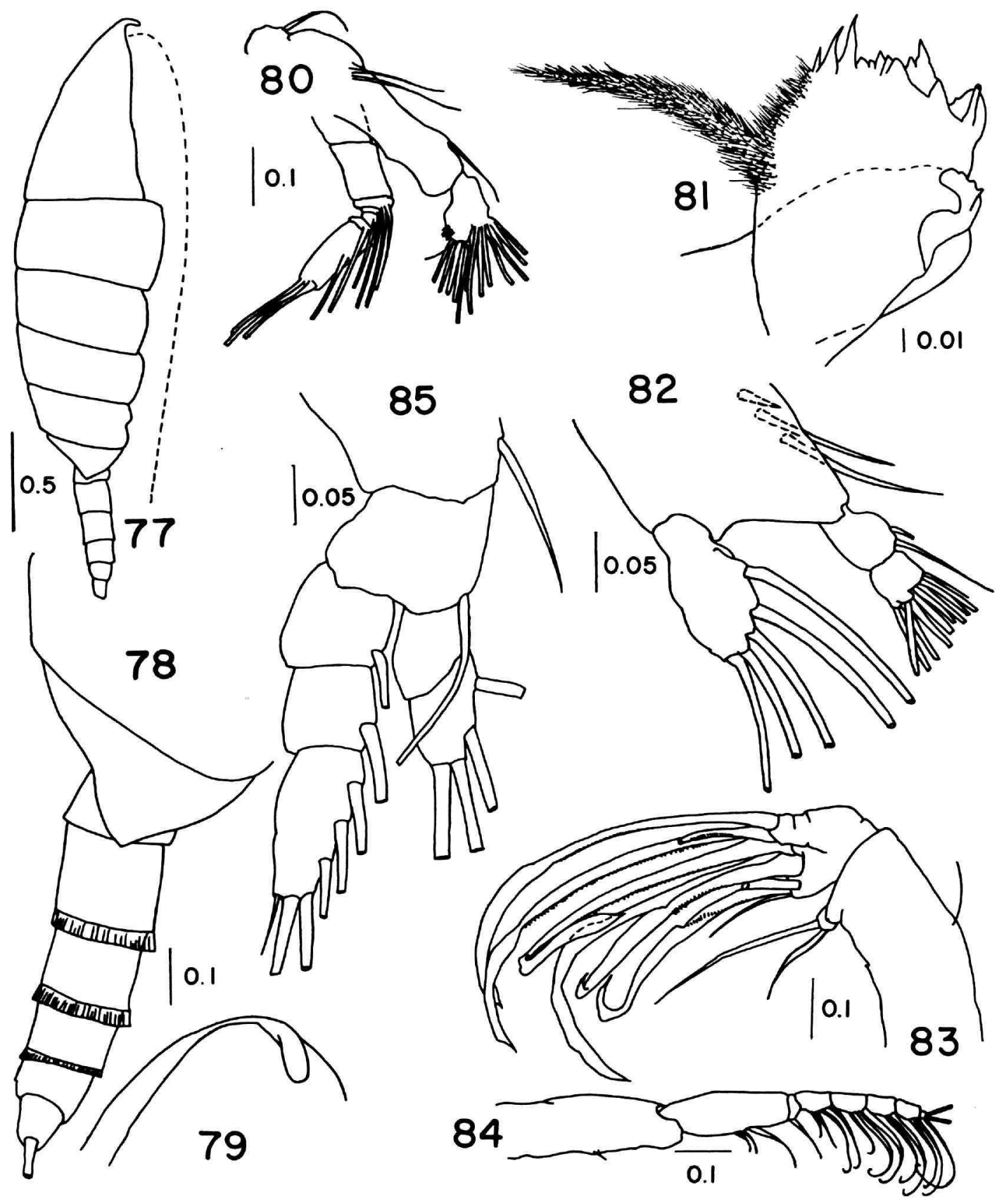

Figures 77-85.-Bathypontia sarsi, male: 77, adult, lateral view; 78, posterior portion of cephalothorax, urosome, lateral view; 79 , rostrum; 80 , second antenna; 81 , gnathal lobe of mandible; 82 , mandibular palp; 83 , second maxilla; 84 , maxilliped; 85 , first leg. 
NUMBER 55

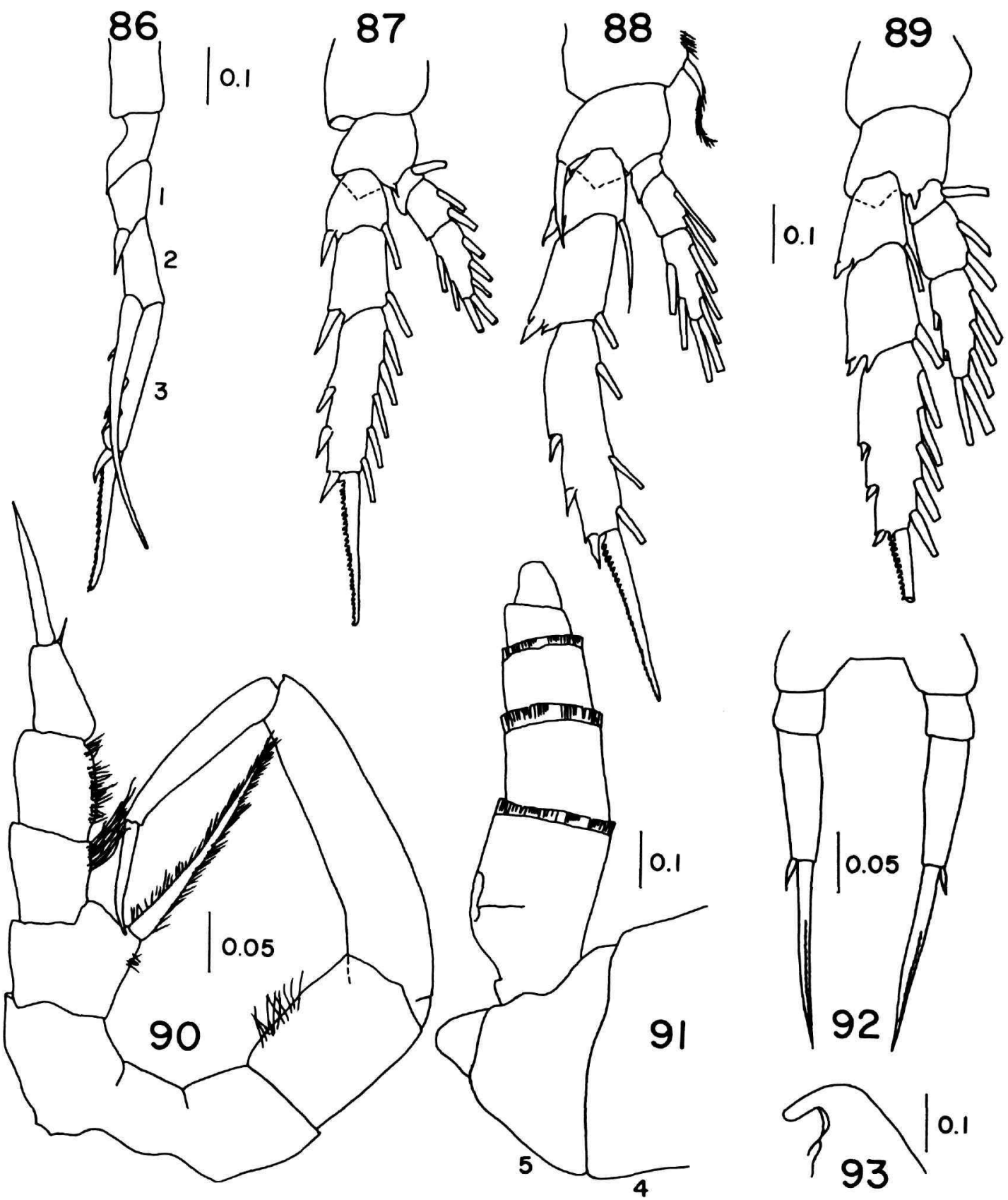

Frgures 86-93.-Bathypontia sarsi, male: 86, right second leg, lateral view; 87 , left second leg; 88, third legs; 89 , fourth legs; 90 , fifth legs. Bathypontia species: 91 , posterior portion of cephalothorax, urosome, lateral view; 92, fifth legs; 93, rostrum, lateral view. 

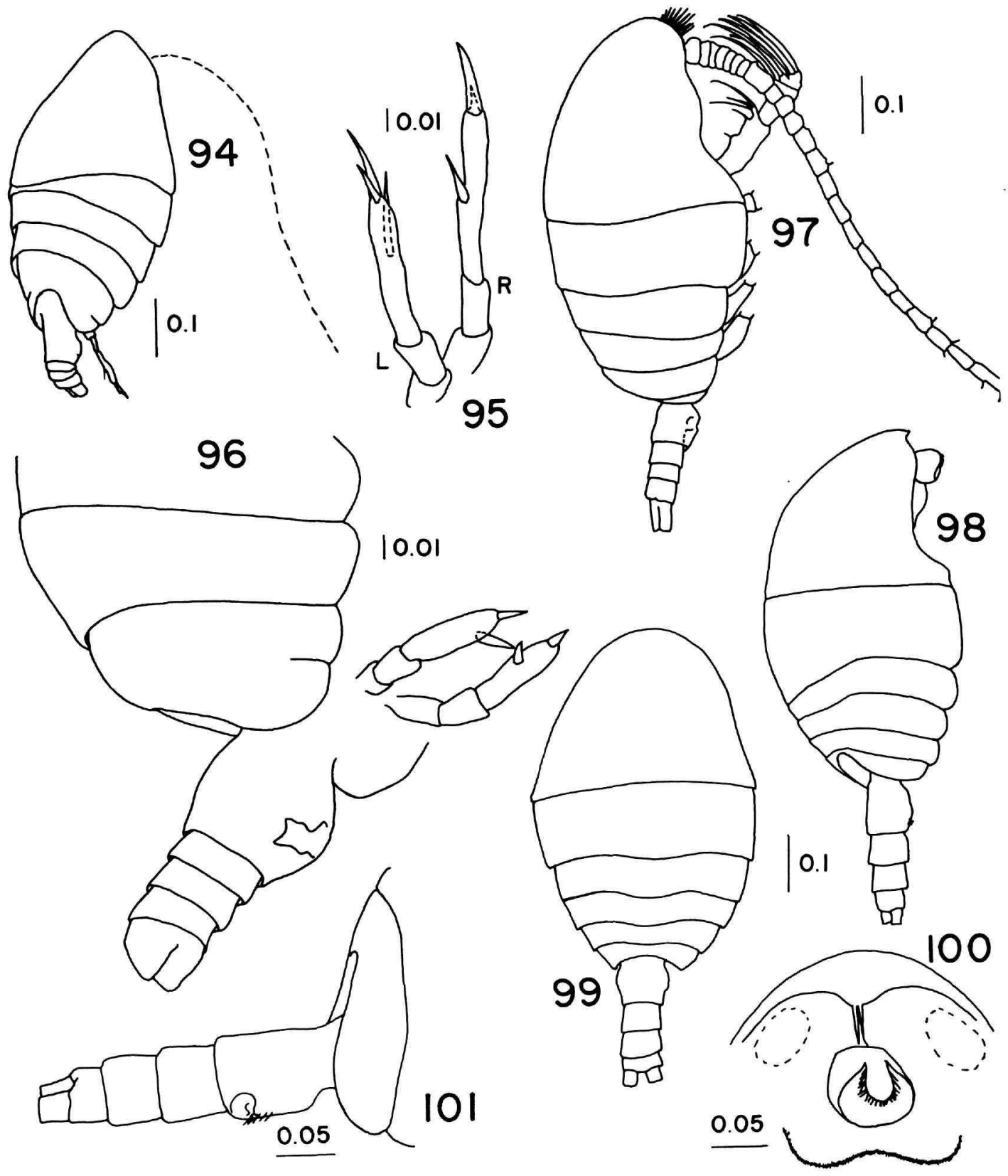

FiguRes 94-101.-Temorites discoveryae, female $(0.64 \mathrm{~mm}): 94$, adult, three-quarter dorsal view; 95, fifth legs. Temorites discoveryae, female $(0.56 \mathrm{~mm}): 96$, posterior portion of cephalothorax, urosome, fifth legs. Foxtonia barbatula, female: 97, adult, lateral view. Zenkevitchiella tridentae, new species, female: 98, adult, lateral view; 99, adult, dorsal view; 100 , anterior portion of head, ventral view; 101, fifth pedigerous segment, urosome, lateral view. 


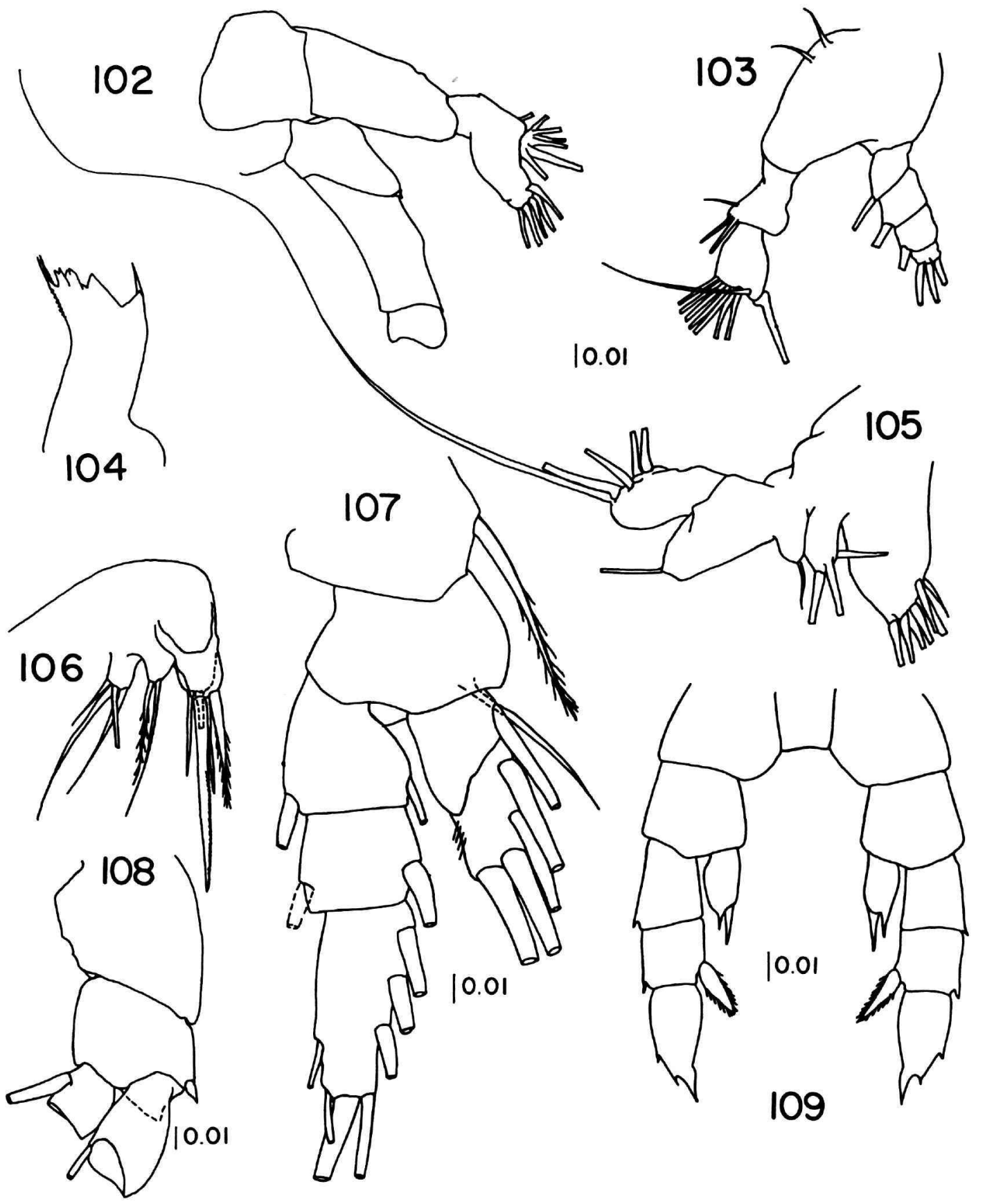

Figures 102-109.-Zenkevitchiella tridentae, new species, female: 102, second antenna, last 4 segments of exopod missing; 103, mandibular palp; 104, gnathal lobe of mandible; 105, first maxilla; 106, second maxilla, terminal segment missing; 107, first leg; 108, third leg, segments 2 , 3 of endopod and exopod missing; 109, fifth legs. 





\section{Publication in Smithsonian Contributions to Zoology}

Manuscripts for serial publications are accepted by the Smithsonian Institution Press, subject to substantive review, only through departments of the various Smithsonian museums. NonSmithsonian authors should address inquiries to the appropriate department. If submission is invited, the following format requirements of the Press will govern the preparation of copy. (An instruction sheet for the preparation of illustrations is available from the Press on request.)

Copy must be typewritten, double-spaced, on one side of standard white bond paper, with $11 / 2$ " top and left margins, submitted in ribbon copy with a carbon or duplicate, and accompanied by the original artwork. Duplicate copies of all material, including illustrations, should be retained by the author. There may be several paragraphs to a page, but each page should begin with a new paragraph. Number consecutively all pages, including title page, abstract, text, literature cited, legends, and tables. The minimum length is 30 pages of typescript and illustrations.

The title should be complete and clear for easy indexing by abstracting services. Taxonomic titles will carry a final line indicating the higher categories to which the taxon is referable: "(Hymenoptera: Sphecidae)." Include an abstract as an introductory part of the text. Identify the author on the first page of text with an unnumbered footnote that includes his professional mailing address. A table of contents is optional. An index, if required, may be supplied by the author when he returns page proof.

Two headings are used: (1) text heads (boldface in print) for major sections and chapters and (2) paragraph sideheads (caps and small caps in print) for subdivisions. Further headings may be worked out with the editor.

In taxonomic keys, number only the first item of each couplet; if there is only one couplet, omit the number. For easy reference, number also the taxa and their corresponding headings throughout the text; do not incorporate page references in the key.

In synonymy, use the short form (taxon, author, date, page) with a full reference at the end of the paper under "Literature Cited." Begin each taxon at the left margin with subsequent lines indented about three spaces. Within a taxon, use a period-dash (.-) to separate each reference. Enclose with square brackets any annotation in or at the end of the taxon. For references within the text, use the author-date system: "(Jones, 1910)" or "Jones (1910)." If the reference is expanded, abbreviate the data: "Jones (1910, p. 122, pl. 20: fig. 1)."

Simple tabulations in the text (e.g., columns of data) may carry headings or not, but they should not contain rules. Formal tables must be submitted as pages separate from the text, and each table, no matter how large, should be pasted up as a single sheet of copy.

For measurements and weights, use the metric system instead of (or in addition to) the English system.

Illustrations (line drawings, maps, photographs, shaded drawings) can be intermixed throughout the printed text. They will be termed Figures and should be numbered consecutively; however, if a group of figures is treated as a single figure, the individual components should be indicated by lowercase italic letters on the illustration, in the legend, and in text references: "Figure 9b." If illustrations (usually tone photographs) are printed separately from the text as full pages on a different stock of paper, they will be termed Plates, and individual components should be lettered (Plate $9 b$ ) but may be numbered (Plate 9: figure 2). Never combine the numbering system of text illustrations with that of plate illustrations. Submit all legends on pages separate from the text and not attached to the artwork.

In the bibliography (usually called "Literature Cited"), spell out book, journal, and article titles, using initial caps with all words except minor terms such as "and, of, the." (For capitalization of titles in foreign languages, follow the national practice of each language.) Underscore (for italics) book and journal titles. Use the colon-parentheses system for volume, number, and page citations: "10(2):5-9." Spell out such words as "figures" and "plates" (or "pages" when used alone).

For free copies of his own paper, a Smithsonian author should indicate his requirements on "Form 36" (submitted to the Press with the manuscript). A non-Smithsonian author will receive 50 free copies; order forms for quantities above this amount with instructions for payment will be supplied when page proof is forwarded. 


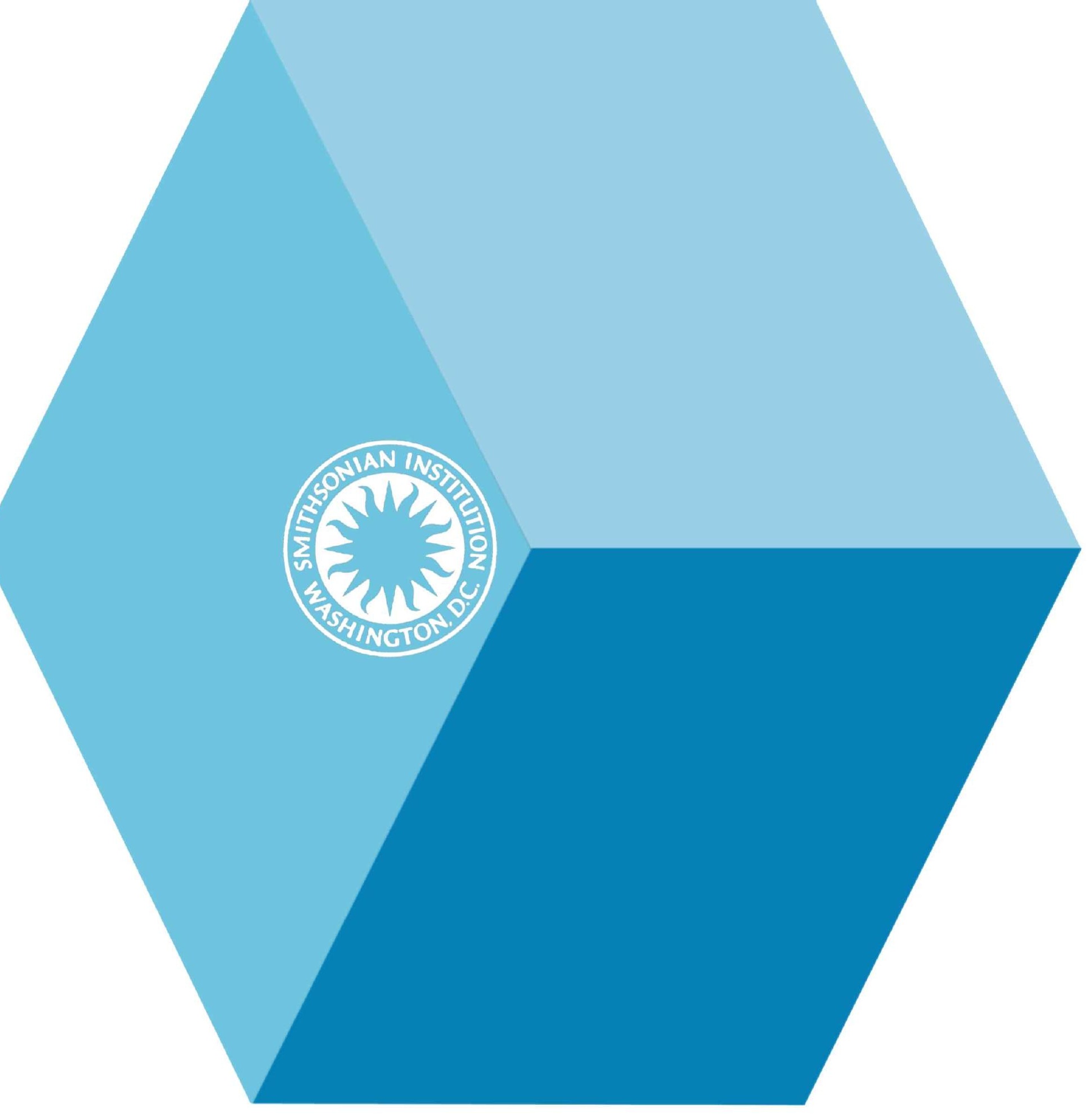

